\title{
The Minimum Balance at Risk: A Proposal to Mitigate the Systemic Risks Posed by Money Market Funds
}

ABSTRACT This paper introduces a proposal for money market fund (MMF) reform to mitigate the systemic risk and externalities that arise from the funds' vulnerability to runs and to protect shareholders who do not redeem quickly when runs occur. Our proposal would require that a small fraction of each MMF shareholder's recent balances, called the "minimum balance at risk" (MBR), be available for redemption only with a delay of 30 days. Most regular transactions in the fund would be unaffected; the requirement would only affect redemptions of the shareholder's MBR. In addition, in the rare event that a fund suffers losses, the MBRs of investors who have recently made large redemptions would absorb losses before those of nonredeeming investors. This subordination of redeeming investors' MBRs would create a disincentive to redeem if the fund is likely to have losses, but would have little effect on incentives when the risk of loss is remote. We use empirical evidence, including a novel data set from the U.S. Treasury and the U.S. Securities and Exchange Commission on MMF losses in 2008, to calibrate an MBR rule that would reduce the vulnerability of MMFs to runs.

y many measures, money market funds (MMFs, or "money funds") are a popular financial product. With \$2.7 trillion in assets under management at the end of 2012, MMFs represented over a fifth of all U.S. mutual fund assets, according to the Investment Company Institute. MMFs are key intermediaries of short-term funding and hold large fractions of 
the short-term debt issued by financial institutions in capital markets. ${ }^{1}$ The popularity of money funds largely reflects the attractiveness of their defining feature for many investors: MMFs, unlike other mutual funds, typically maintain a stable $\$ 1.00$ share price (also known as the fund's "net asset value," or NAV). Their stability of principal allows MMFs to serve as an important cash management tool for individuals, firms, institutions, and governments.

However, MMFs are vulnerable to runs, and given the size of the money fund industry and its importance in allocating short-term funding to financial institutions, this vulnerability poses considerable risk to the financial system. The potentially dire consequences of a run on MMFs were evident in September 2008, when the Lehman Brothers bankruptcy caused one fund to "break the buck" (that is, its NAV fell below $\$ 1$, so its investors suffered principal losses) and triggered massive and widespread redemptions from other MMFs. ${ }^{2}$ These outflows were a key factor in the virtual shutdown of short-term funding markets and a broader curtailment of credit supply (see, for example, Federal Open Market Committee 2008, Board of Governors of the Federal Reserve System 2009, U.S. Securities and Exchange Commission 2009, President's Working Group on Financial Markets 2010). The severity of the damage to financial stability caused by the run in 2008 led to unprecedented government interventions to support MMFs in order to halt the run. Since then, the funds' vulnerability has continued to pose risks to the financial system. The heavy exposures of MMFs to European financial institutions, for example, have put the funds at risk of transmitting strains from Europe very rapidly to U.S. short-term funding markets (Financial Stability Oversight Council 2011, Chernenko and Sunderam 2013). Yet policymakers have fewer tools available now to address MMF runs than they did in 2008; in particular, the Treasury's Temporary Guarantee Program for Money Market Funds, which effectively halted the run

1. For example, at the end of 2012, MMFs owned over 40 percent of outstanding dollardenominated financial commercial paper (short-term debt issued by financial corporations, usually with maturities of under 90 days). The funds also owned 29 percent of banks' large time deposits (deposits with fixed maturities in amounts of $\$ 100,000$ or more) issued in the United States. These figures come from MMF filings of U.S. Securities and Exchange Commission form N-MFP, the Depository Trust \& Clearing Corporation, and Federal Reserve Flow of Funds data.

2. Like other "open end" mutual funds, MMFs transact directly with shareholders (investors), who can purchase shares from the MMF or redeem shares (sell them back to the fund) at a price equal to the fund's NAV. In a run on an MMF, investors redeem shares immediately, possibly only because they believe they otherwise would be harmed by the effects of other investors' redemptions. 
in 2008, would no longer be possible under current law: the Emergency Economic Stabilization Act of 2008 specifically prohibits the Treasury from reusing that mechanism. In light of the systemic risk stemming from MMFs' susceptibility to runs, calls for reform have come from government agencies (for example, Schapiro 2010, 2011, 2012, President's Working Group on Financial Markets 2010, Financial Stability Oversight Council 2011, 2012a, 2012b), from academics (for example, Squam Lake Group 2011, Hanson, Scharfstein, and Sunderam 2012), and from the financial industry (for example, Mendelson and Hoerner 2011, Goebel, Dwyer, and Messman 2011).

This paper proposes a new approach to mitigating the vulnerability of MMFs to runs by introducing a "minimum balance at risk" (MBR) that could provide a disincentive to run from a troubled money fund. ${ }^{3}$ The MBR would be a small fraction (for example, 5 percent) of each shareholder's recent balances that could be redeemed only with a delay. The delay would ensure that redeeming investors remain partially invested in the fund long enough (we suggest 30 days) to share in any imminent portfolio losses or costs of their redemptions. However, as long as an investor's balance exceeds her MBR, the rule would have no effect on her transactions, and no portion of any redemption would be delayed if her remaining shares exceed her minimum balance.

An MBR could be introduced in a manner that preserves the basic features of MMFs. Funds could, for example, maintain stable \$1 NAVs and honor most transactions without any delay or restrictions. The loss allocation rules that are central to the MBR concept would affect shareholders' actual balances only in the event that a fund breaks the buck and closes. Implementation would require an MMF to track just two additional variables for each investor: her MBR and any portion of her MBR that she has requested to redeem. Importantly, the MBR concept could be introduced together with other reforms. In particular, we suggest that an MBR would work well in tandem with a capital buffer requirement for money funds.

An appropriately designed MBR would have several benefits. By discouraging investors from redeeming from a troubled MMF, an MBR would

3. We originally proposed the MBR in a July 2012 working version of this paper, available at www.newyorkfed.org/research/staff_reports/sr564.pdf. The Financial Stability Oversight Council subsequently incorporated the MBR, much as we described it there, in its "Proposed Recommendations Regarding Money Market Mutual Fund Reform" (Financial Stability Oversight Council 2012b). Alternative Two in the Financial Stability Oversight Council's proposed recommendations would require MMFs to have MBRs. See section I below. 
help prevent a run and its destabilizing and costly repercussions. This not only would benefit the fund and its investors but also would mitigate the externalities that result from an MMF's potential to propagate strains throughout the financial system. An MBR also would benefit investors who are not prone to redeem shares quickly at the first sign of trouble for an MMF. In particular, retail investors (small, typically individual investors, as distinct from institutional investors such as corporate treasurers), who historically have been less quick to run from distressed funds, would enjoy additional protections because the MBR would prevent nonredeeming shareholders from shouldering all losses in the event that a fund breaks the buck. Moreover, by clarifying that investors cannot avoid imminent losses by redeeming shares quickly in a crisis, an MBR should strengthen incentives for early market discipline for MMFs and motivate investors to identify potential problems in a fund long before any losses occur.

We begin in section I with a discussion of the structural vulnerability of MMFs to runs and recent proposals for reform. Section II outlines the MBR concept, and section III illustrates how an MBR would counter investors' incentives to redeem shares in a troubled MMF. Section IV reviews empirical evidence, including that from a novel data set from the U.S. Department of the Treasury and the U.S. Securities and Exchange Commission (SEC) on MMF losses during September and October 2008, to calibrate an MBR rule that would reduce the vulnerability of MMFs to runs. Section V discusses policy issues relevant to the introduction of an MBR. Section VI concludes the paper.

\section{Background, Policy Context, and Literature}

The vulnerability of MMFs to runs can, in large measure, be traced back to their stable $\$ 1 \mathrm{NAVs}$, to the characteristics of investors who are attracted to stable-value funds, and to the methods that MMFs use to maintain price stability. Like other mutual funds, MMFs provide maturity and liquidity transformation by holding a combination of highly liquid assets and less liquid, longer-dated securities while allowing shareholders to redeem shares on demand. But unlike other mutual funds, MMFs redeem shares at a price that almost never varies from $\$ 1$ per share (or, in a few MMFs, from $\$ 10$ per share). Indeed, the historical success of the funds in maintaining principal stability (only two money funds have "broken the buck" since 1983, when the SEC adopted rule 2a-7 to govern MMFs) has attracted a large, highly risk-averse shareholder base that includes many sophisticated 
institutional investors. ${ }^{4}$ These shareholders reportedly view principal stability as the "hallmark" feature of MMFs (Investment Company Institute 2009, Stevens 2011) and hence are prone to pulling out of an MMF quickly at any sign of trouble.

Although the stable NAV is critical for many MMF investors, no capital buffer or insurance guarantees a money fund's $\$ 1$ share value. Instead, MMFs have relied on a combination of strict SEC rules on portfolio composition, the ability to round their NAVs to the nearest cent (see the previous footnote), and when all else fails, financial support from their sponsors (investment management firms and their affiliates) when they have the wherewithal to provide it (Moody's Investors Service 2010, Rosengren 2012, Schapiro 2012, Brady, Anadu, and Cooper 2012, Financial Stability Oversight Council 2012b). Importantly, this support is voluntary and provided on a discretionary basis; sponsors are not required to support an ailing fund, either by regulation or by contract.

However, if shareholders begin to doubt the ability of these mechanisms to prevent losses, they have strong incentives to redeem shares before others do. Institutional shareholders appear to be particularly attuned to these incentives (President's Working Group on Financial Markets 2010, McCabe 2010, Chernenko and Sunderam 2013). The imperative to be the first to exit means that any sign of serious strains for an MMF-or concerns that other shareholders perceive such a problem-may be enough to trigger a run.

The incentive to redeem before others do arises largely because investors who redeem shares from a troubled MMF may benefit by imposing costs on other shareholders. This uneven allocation of risks and losses between redeeming and nonredeeming shareholders results from the same money fund practices and features that help maintain the stable NAV. Most importantly, because MMFs round their NAVs to the nearest cent, an investor who redeems shares from a fund that has incurred a loss of less than 0.5 percent can still obtain $\$ 1$ per share. In effect, the fund transfers a redeeming shareholder's pro rata share of the loss to the fund's nonredeeming shareholders, as the loss is concentrated over a shrinking number of shares.

4. The SEC adopted rule 2a-7 under the Investment Company Act of 1940 to allow MMFs to use procedures that help maintain a stable NAV. Most notably, rule 2a-7 allows a fund to round the underlying market value of its shares to the nearest cent when calculating its NAV. In return for allowing these procedures, rule 2a-7 places restrictions on MMF portfolios with regard to credit quality, liquidity, maturity, and diversification. Rule $2 \mathrm{a}-7$ has been amended several times since 1983, most recently in 2010, when portfolio restrictions were tightened and new reporting requirements added. 
MMFs' liquidity management practices also contribute to principal stability while heightening the advantages for investors who redeem quickly from troubled money funds. MMFs typically meet redemptions by disposing of their more liquid assets, rather than by selling a cross section of their holdings. Redeemers who receive $\$ 1$ per share thus bear none of the liquidity costs of their redemptions and leave nonredeeming investors with claims on a less liquid portfolio.

MMFs' imperative to maintain a stable NAV (and comply with rule 2a-7) also leads the funds to hold similar portfolios, a fact that contributes to contagion risk among MMFs. That is, redemptions from one MMF can hurt shareholders in other funds. Money funds generally can hold only assets with the highest short-term ratings, and given the relatively small number of private firms with such ratings, MMFs that provide funding to private firms tend to have exposures to similar sets of counterparties-mostly large financial institutions. As of September 30, 2012, for example, 50 private issuers accounted for 91 percent of the nongovernmental investments of prime MMFs, which largely invest in short-term debt instruments issued by private firms, and all but 4 of these 50 issuers were financial firms. ${ }^{5}$ Redemptions that force one MMF to sell less liquid assets may put downward pressure on the prices of these assets (particularly given the thinness of secondary markets for many money market instruments), place other MMFs at risk of suffering losses, and prompt shareholders in those funds to redeem shares preemptively.

The severity of the run on MMFs in September 2008 and its broader consequences prompted calls for reforms to mitigate the systemic risks arising from MMFs' structural vulnerability to runs. Subsequent concerns that the funds might transmit strains from the European debt crisis to U.S. short-term funding markets provided further motivation for reform (Financial Stability Oversight Council 2011, Schapiro 2011, Rosengren 2012).

In 2010 the SEC adopted amendments to rule 2a-7 to make MMFs more resilient to market disruptions by, for example, tightening liquidity, maturity, credit quality, and disclosure requirements. Nonetheless, as these reforms were adopted, SEC Chairman Mary Schapiro recognized a need "to pursue more fundamental changes to the structure of money market funds to further protect them from the risk of runs" (Schapiro 2010). Later that year the President's Working Group on Financial Markets (PWG) "agree[d] with the SEC that more should be done to address MMFs' susceptibility to runs" and offered eight options for reducing this vulnerability (PWG

5. These figures are based on our own calculations using SEC form N-MFP data for prime MMFs. See also Scharfstein (2012) and Hanson and others (2012). 
2010, p. 1). ${ }^{6}$ In August 2012, however, Chairman Schapiro announced that the SEC would not vote to propose further MMF reforms. A month later, Treasury Secretary Timothy Geithner requested that the Financial Stability Oversight Council (FSOC) use its authority to recommend that the SEC address the systemic risks posed by MMFs. The FSOC issued proposed recommendations in November 2012, including three alternatives for MMF reform: the first would require MMFs to have a floating NAV, the second called for an MBR paired with a small capital buffer, and the third proposed a larger capital buffer, possibly combined with other measures (FSOC 2012b). In June 2013 the SEC proposed two options for MMF reform: a floating NAV for prime MMFs sold to institutional investors and a requirement that funds impose or consider fees and restrictions for redemptions if their liquid assets fall below a threshold (U.S. SEC 2013).

More generally, proposals for MMF reform have focused on three possible alternatives to the MBR for mitigating the funds' vulnerability to runs: a switch to floating NAVs, a mandate that funds maintain capital buffers, and requirements that MMFs impose fees or other (non-MBR) restrictions on redemptions. All three options have merits and drawbacks. For example, the floating NAV, which has been advocated by, among others, the Group of Thirty (2009), Jeffrey Lacker (2011), the Wall Street Journal, ${ }^{7}$ and Paul Volcker (2011), could eliminate the destabilizing consequences of NAV rounding and remove the discontinuity in MMF pricing - and some of the resulting disruptions-when share values fall below the 99.5 cent threshold. But MMFs with floating NAVs probably would remain at some risk of runs, in part because the funds' liquidity management practices would continue to give an advantage to early redeemers from funds with limited liquid assets (see, for example, Hanson and others 2012, Gordon and Gandia 2013). A full analysis of the relative merits of other reform options is beyond the scope of this paper, but we discuss their pros and cons in some detail in section $\mathrm{V}$.

\section{The Minimum Balance at Risk}

The minimum balance at risk that we propose in this paper is a new approach to MMF reform that would mitigate the risk of runs by limiting the ability of redeeming investors to benefit by imposing risks, costs, and

6. The PWG, which was essentially the predecessor of the Financial Stability Oversight Council, comprised the secretary of the Treasury, the chairman of the Board of Governors of the Federal Reserve System, the chairman of the SEC, and the chairman of the Commodity Futures Trading Commission.

7. “Taxpayers and Money Market Funds [Editorial]," Wall Street Journal, May 9, 2011. 
losses on nonredeemers. The MBR would be a small fraction (for example, 5 percent) of some measure of each investor's recent balances. The investor could redeem her MBR only with a delay, which would need to be sufficient (we suggest 30 days) to ensure that she remains partially invested in the fund long enough to share in any imminent portfolio losses or costs of her redemptions. The MBR would have no effect on an investor's transactions in the fund as long as her remaining shares exceed the MBR.

The MBR rule that we describe would impose no losses on any investor unless that investor's MMF breaks the buck. In the rare event that an MMF does break the buck and liquidate, the MBR rule would allocate losses differently than under current rules, which divide losses solely in proportion to each investor's shares in the fund when it closes. Importantly, an MBR would make investors who otherwise would have redeemed all of their shares shoulder some of a fund's losses.

Conceptually, the MBR straddles the two main proposed approaches to shoring up MMFs' stable NAVs: capital buffers and redemption restrictions. By identifying a minimum portion of each investor's balance that would be at risk for absorbing losses-whether or not the investor redeems shares-the MBR essentially would serve a function similar to that of capital. As a form of redemption restriction, the MBR rule would always be in place, so investors could not redeem preemptively to avoid the restriction. (In contrast, redemption restrictions that are imposed only in times of stress may increase the risk of MMF runs by creating an incentive to run before the restrictions are imposed.) But even though the MBR would be in place at all times, it would have no effect on most transactions in a fund, particularly during normal times. Only when an MMF appears to be at risk of losses would the MBR materially affect investors' incentives to redeem shares.

\section{II.A. Basic Features}

The MBR would be determined individually for each investor based on his "reference amount" $R$, which might be his maximum balance ("highwater mark") in the fund over the previous 30 days or his 30-day-average balance, or some other function of his recent balances. Any reference amount should be calculated excluding any shares that have been held back (that is, made subject to redemption with a delay).

The MBR for investor $i$ would be a fraction $m$ of the investor's reference amount. That is, $M B R_{i}=m R_{i}$. For illustration, we discuss a rule with $m=5$ percent; in any case, $m$ should be large enough to give investors confidence 
that, in a crisis, their MMF's losses would not exceed its aggregate MBR, that is, the sum of all its shareholders' MBRs.

An investor with a total balance $B$ would have an available balance equal to $B-M B R$. As long as the investor's requested redemption would not bring his balance below his MBR, his transactions would be unaffected by the MBR rule. However, when the investor places a redemption request that would bring his balance below the MBR, any shortfall relative to the MBR would be redeemed with a delay. We propose a delay of 30 days.

Both the redemption delay and the period over which $R$ is calculated should be long enough to minimize the opportunity for preemptive runs. If the delay is short, informed shareholders may continue to see redemptions at the first sign of a problem as an effective way to obtain full payment for all their shares before any losses are realized. The MBR in that case might even be destabilizing, since such investors might redeem all shares as fast as possible in the hope that the delay period passes before any material losses are realized. The 30-day delay that we propose should be long enough to minimize the effectiveness of such a strategy. ${ }^{8}$

\section{II.B. Creating a Disincentive for Shareholders to Redeem}

To be effective in braking redemptions from a troubled MMF and mitigating the externalities associated with runs, an MBR rule must create a disincentive for redemptions that is strong enough to counter investors' powerful reasons to redeem when an MMF is under strain. Since the MBR works by affecting the allocation of losses only in the event that a fund breaks the buck, a sensible way to create such a disincentive is by stipulating that redeeming investors absorb losses in the fund before other investors. The MBR rule that we propose would cause some or all of a redeemer's MBR to be subordinated relative to nonredeemers' MBRs. That is, if an MMF breaks the buck, redeeming shareholders' MBRs would absorb losses before nonredeemers' MBRs do. Thus, as long as losses do not exceed a fund's aggregate MBR, redeeming shareholders would shoulder a larger share of the losses than nonredeemers.

8. Section IV.E discusses the appropriate length for the delay period in more detail. In addition, the period over which $R$ is computed should be as long as the redemption delay period, since a shorter period for calculating $R$ would allow investors to circumvent the delay period for all but a tiny portion of their shares by redeeming all available balances and waiting a few days for the reference amount to decline. 
Specifically, the fraction of a redeeming investor's MBR that is subordinated would be the fraction of his available shares that he has redeemed. That is,

$$
\text { subordinated balance }=\operatorname{MBR} \times\left(\frac{\text { cumulative net redemptions }}{\text { potential redemptions }}\right) .
$$

Cumulative net redemptions are the investor's reference amount less his current balance (zero if his balance exceeds his reference amount). ${ }^{9}$ For example, if the reference amount is defined to be the investor's 30-day high-water mark, his cumulative net redemptions would be the high-water mark less his current balance. Potential redemptions are his reference amount less his MBR. Thus,

$$
\text { subordinated balance }=\mathrm{MBR} \times\left(\frac{\text { reference amount }- \text { current balance }}{\text { reference amount }-\mathrm{MBR}}\right) \text {, }
$$

as long as the reference amount exceeds the current balance (otherwise, the subordinated balance is zero). Hence, all that is needed to compute the subordinated balance is the investor's reference amount, his MBR (which is just a fixed proportion of his reference amount), and his current balance. For example, if an investor redeems all his available shares, his current balance is his MBR, the ratio of cumulative net redemptions to potential redemptions is 1 , and the investor's entire MBR would be subordinated. If his net redemptions total only half of his potential redemptions, then half of his MBR would be subordinated.

Subordination of redeemers' MBRs has several advantages. First, as mentioned above, creating a disincentive to redeem is essential to achieving substantial reduction of the risk of runs on MMFs. An MBR without subordination of redeemers' balances only partly mitigates the incentive to run, and given the intensity of incentives to redeem from a troubled MMF, investors without a disincentive to run still should be expected to run. Second, the automatic strengthening of the disincentive when an MMF encounters trouble would allow the subordination rule to be in effect at all times without imposing an undue burden on a fund and its investors. Only in the event that a fund experiences problems would the disincentive

9. If the investor's reference amount is his high-water mark, his balance cannot exceed his reference amount. 
become large enough to offset incentives to redeem. Even then, the rule still would allow redemptions, but investors would face a trade-off between redeeming shares to preserve liquidity and remaining invested to safeguard principal. Notably, the strengthening of the disincentive for redemptions would not require intervention by a fund's board or by government officials. Third, a disincentive based on subordination would allocate losses among investors only when an MMF breaks the buck - that is, in circumstances in which investors would lose money under current rules, too-but losses would be allocated first to those who have recently redeemed and who thus contributed most to strains on the fund. Fourth, the MBR would strengthen incentives for early market discipline for MMFs by clarifying that investors cannot quickly redeem all shares from a fund during a crisis. Since investors would have strong incentives to identify potential problems well before any losses are realized, the market discipline encouraged by the MBR likely would be based more on investors' assessments of the riskiness of a fund's strategy or operations, rather than on headlines that trigger runs. Thus, redemptions that result from incentives created by the MBR probably would be diffuse rather than concentrated and destabilizing.

\section{II.C. A Retail Exemption}

The MBR concept is quite flexible, and a variety of adjustments could be made to accommodate normative concerns. For example, some adjustments to the MBR rule may be desirable to protect investors who make small, routine redemptions from triggering subordination of their MBRs. One adjustment would exempt the first $\$ 50,000$ of an investor's redemptions from subordination. An investor who redeems less than $\$ 50,000$ still would be subject to the MBR, but none of her MBR would be subordinated. ${ }^{10}$ Specifically, the rule would be

subordinated balance $=\operatorname{MBR} \times\left(\frac{\text { cumulative net redemptions }-\$ 50,000}{\text { potential redemptions }}\right)$,

for cumulative net redemptions in excess of $\$ 50,000$, and zero otherwise. ${ }^{11}$

10. Alternative Two of the FSOC's proposed recommendations would provide a $\$ 100,000$ exemption both from the MBR and from any subordination (FSOC 2012b).

11. We are grateful to Eric Rosengren for suggesting, during discussions with staff at the Federal Reserve Bank of Boston, the possibility of a threshold below which subordination would not apply. 
Thus, any investor with a balance of under $\$ 50,000$ would never have any portion of her MBR subordinated, so the adjustment would exempt many retail MMF accounts from subordination. This may be appropriate, given that retail investors are generally much less prone to run from distressed MMFs than are institutional investors. ${ }^{12}$ Of course, a $\$ 50,000$ exemption for redemptions would reduce protections for nonredeeming investors, especially in retail MMFs. However, investors would continue to be protected by the MBR itself, which would ensure that redeeming investors share proportionally in any losses of principal as long as losses do not exceed the fund's aggregate MBR.

\section{II.D. Loss Allocation Rules with an MBR}

In the event that an MMF with an MBR rule suffers losses, we assume that those losses would be allocated in the following order:

- Losses would be allocated first to a capital buffer (if any). The MBR rule that we propose would work well in tandem with a capital buffer, since a well-calibrated MBR rule would make liquidityrelated losses less likely for MMFs and hence make a buffer of any size more effective. Moreover, a capital buffer would augment an MBR in mitigating investors' incentives to redeem when a fund suffers a loss. We assume that if losses exceed the capital buffer, the fund would be liquidated and remaining losses would be distributed according to the MBR rule. ${ }^{13}$

-Any losses in excess of the buffer would be absorbed on a pro rata basis by the subordinated portions (if any) of shareholders' MBRs.

- Any additional losses would be absorbed on a pro rata basis by the remaining portions of shareholders' MBRs.

12. Retail MMFs were much less likely than their institutional counterparts to suffer very large outflows during the run in 2008 (PWG 2010, McCabe 2010), and retail funds experienced relatively small net outflows in the summer of 2011, when concerns about MMFs' European exposures and the possible consequences of a breakdown in debt ceiling negotiations triggered large redemptions from institutional MMFs (see, for example, Chernenko and Sunderam 2013). Indeed, differences in the riskiness of retail and institutional funds led the SEC to consider different liquidity requirements for the two types in its proposed amendments to rule 2a-7 (U.S. SEC 2009). However, many MMFs have both retail and institutional investors - this was one factor that led the SEC not to adopt such a distinction (U.S. SEC 2010).

13. This assumption rules out an MMF rounding up its share price to $\$ 1$ and hence redeeming shares for more than their underlying value ("dilutive redemptions"). See section III for further discussion. 
- Any remaining losses would be divided on a pro rata basis over all other shares in the fund.

\section{A Closer Look: Incentives to Redeem under Different MBR Rules}

Here we use a stylized example to illustrate the MBR concept and the relative effectiveness of different MBR rules in discouraging runs on money funds. Specifically, we examine how an MBR would affect the incentives of an MMF shareholder when she learns that her MMF is in distress. We show that investors' decisions to redeem depend not only on the principal losses that the fund might suffer, but also on the liquidity costs associated with losing access to cash invested in an MMF that closes. ${ }^{14}$ We also explore how different MBR rules affect the linkages between one investor's losses and other investors' redemptions.

We consider an MMF with an MBR of 5 percent of investors' recent high-water marks (their reference amounts), and we focus on outcomes for small investors who each own 0.1 percent of the fund's assets. To illustrate how an MBR might complement a small, NAV-stabilizing capital buffer, we assume that the fund has a 0.5 percent ( 50 basis point) buffer, so that in normal times it maintains a mark-to-market ("shadow") NAV of $\$ 1.005 .{ }^{15}$ Losses are absorbed first by this buffer, and as long as losses are smaller than 0.5 percent, the fund can remain open and no losses are imposed on shareholders. Any losses exceeding the buffer force the closure of the fund, however, and are allocated first to subordinated MBRs, then to nonsubordinated MBRs, and finally to other MMF shares, as described in section II.D. The assumption that the fund must close if its shadow NAV falls below $\$ 1$ rules out dilutive redemptions (that is, investors receiving $\$ 1$ for shares when the shadow NAV falls below $\$ 1$ ), which are costly for nonredeeming shareholders. ${ }^{16}$ Indeed, in part because the NAV-stabilizing buffer can eliminate the rationale for allowing dilutive redemptions, we

14. We analyze these incentives more formally in a simple model in section 4 of our working paper.

15. A money fund's shadow NAV is essentially the market value of its portfolio divided by the number of its shares. Under current rules an MMF can maintain a stable \$1 NAV as long as its shadow NAV does not deviate by more than one-half cent from $\$ 1$.

16. Relaxing this assumption would generally increase the advantages enjoyed by redeeming shareholders, so MMFs that allow dilutive redemptions would need larger MBRs to reduce the threat of runs than would funds that do not allow dilutive redemptions. 
Figure 1. Investor Losses with No MBR, When Others Do Not Redeem ${ }^{\mathrm{a}}$

Investor's loss (percent of preredemption holdings)

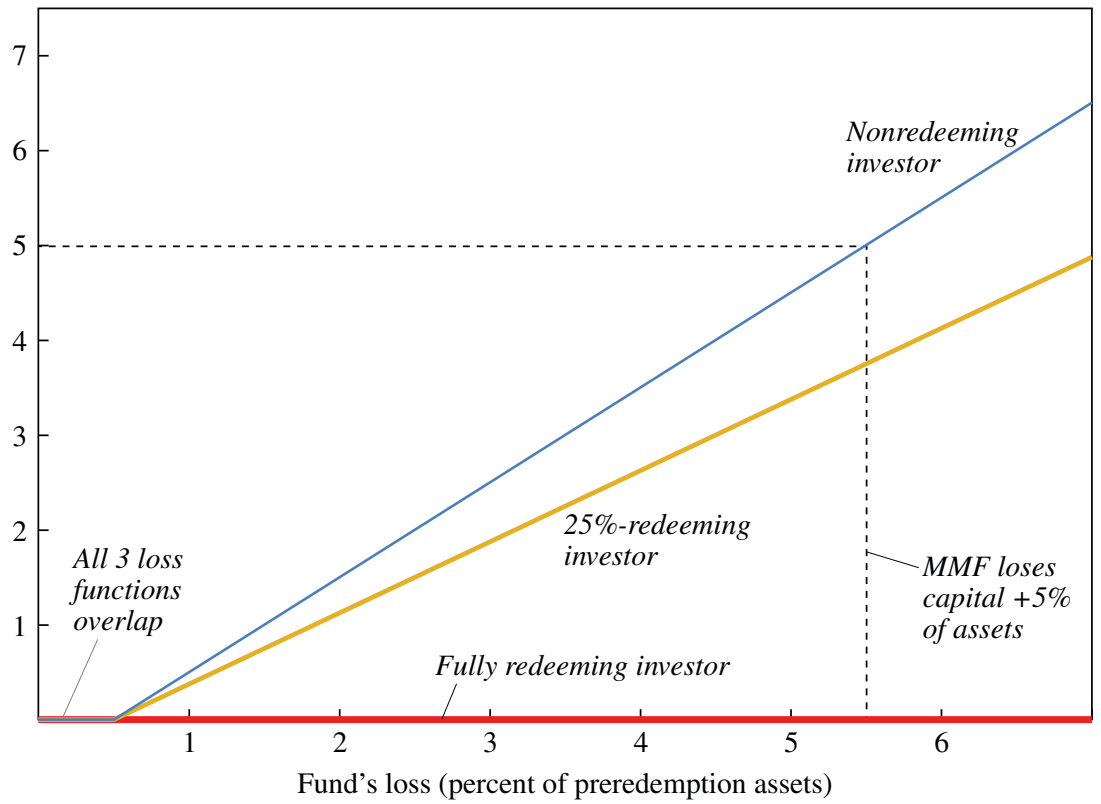

Source: Authors' model described in the text.

a. In the absence of an MBR, the fund's losses are allocated first to any capital buffer (here assumed to be 0.5 percent), and beyond that to the fund's investors in proportion to their unredeemed shares. For a fund that loses 5.5 percent of assets (vertical dashed line), if redemptions by other investors are trivial, a nonredeeming investor would lose 5 percent, while losses would be 25 percent less for an investor who has redeemed 25 percent of her shares. A fully redeeming investor would lose nothing.

suggest that an MBR be introduced with such a buffer and that dilutive redemptions be banned.

\section{III.A. No MBR (Status Quo but with a 0.5 Percent Capital Buffer)}

Figure 1 shows how individual shareholders' losses would vary with the losses in an MMF without an MBR, a situation equivalent to the status quo except that we assume that the fund also has a 0.5 percent capital buffer. ${ }^{17}$ We consider three investors: one who redeems all shares just before the losses are realized (the "fully redeeming investor"), one who redeems 25 percent of her shares, and one who redeems no shares. Each investor's

17. Strictly speaking, the MMF modeled in this section differs in two respects from the status quo: it has a 0.5 percent $\mathrm{NAV}$-stabilizing buffer, and it allows no dilutive redemptions (it closes when losses exceed the buffer). 
losses are plotted as a fraction of her preredemption assets (which are assumed to be her reference amount). ${ }^{18}$ In showing losses for each investor, we also assume that others' redemptions from the fund are trivial.

As long as the fund's losses do not exceed 0.5 percent, the fund stays open and no investor incurs a loss. However, once losses exceed 0.5 percent, stark differences emerge. The fully redeeming investor bears no loss under any circumstance. The investor who redeems nothing suffers losses in proportion to the fund's losses in excess of 0.5 percent. For example, in the case illustrated by the dashed lines, if the fund loses 5.5 percent, the nonredeeming investor loses 5 percent. The investor who redeems 25 percent of her available balance just before the fund's loss experiences only 75 percent of the losses that the nonredeeming shareholder suffers.

Figure 1 illustrates only part of investors' strong incentive to run under current rules, even with the small, NAV-stabilizing buffer. Those who redeem immediately before a loss is reflected in a fund's share price are able to shield themselves from any loss of principal. A second reason to run is that other shareholders' redemptions at $\$ 1$ per share concentrate losses on the remaining shareholders. The losses incurred by the nonredeeming investor thus depend on the behavior of other investors. Figure 2 illustrates this point by relaxing the assumption in figure 1 that redemptions by other investors are trivial. In this case the losses for a nonredeeming investor grow (the upward-sloping region of the loss function rotates to the left) as the fraction of shares that others redeem rises from zero to 25 percent and 50 percent. In contrast, the fully redeeming shareholder's losses are still unaffected by others' redemptions: that shareholder's losses are zero in all cases. This sharp disparity in outcomes for redeeming and nonredeeming investors highlights the problem that, under current rules, when a fund is perceived to be in trouble, investors have a strong incentive to rush for the exits before others do.

A third reason to redeem quickly from an MMF in trouble is that others' redemptions can force the fund to sell assets, which may be costly for nonredeeming shareholders (this point is not illustrated in our charts). For example, if a fund suffers losses because it must dispose of illiquid assets to raise cash, nonredeeming investors shoulder at least a portion of those losses and thus effectively subsidize redeeming investors. Even if a fund has

18. In contrast, a comparison of investors' losses as a percentage of the shares they hold at the time of a fund's closure would fail to take into account the cash that redeeming investors have removed from the fund. Thus, it would overstate the redeeming investors' total losses as a share of their holdings at the time they make the decision to redeem or remain invested. 
Figure 2. Investor Losses with No MBR, When Others Redeem ${ }^{\mathrm{a}}$

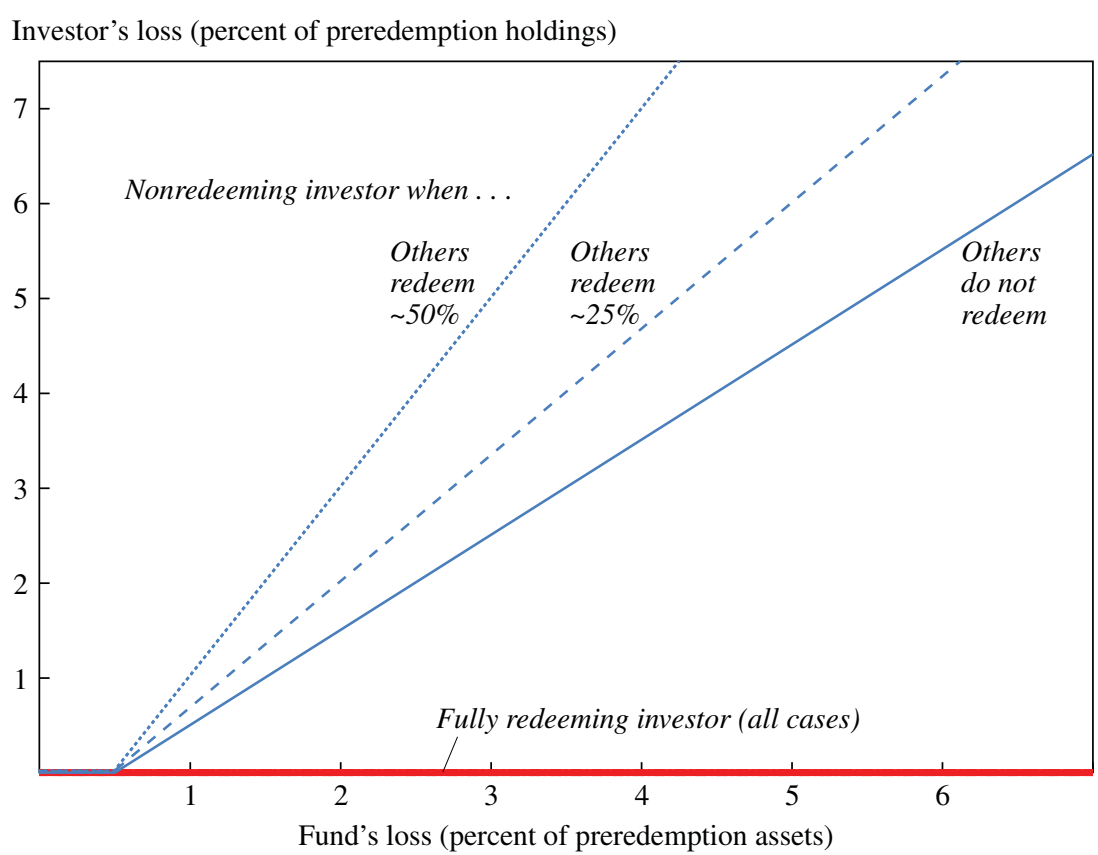

Source: Authors' model described in the text.

a. In the absence of an MBR, when redemptions by other investors are not trivial, losses exceeding any capital buffer are borne by nonredeeming investors and rise with the fraction of shares that others redeem. The losses for the fully redeeming investor do not depend on the actions of other investors and are zero in all cases.

enough liquid assets to raise cash without suffering losses, heavy redemptions leave remaining investors with claims on a less liquid portfolio.

A fourth reason for an MMF shareholder to redeem quickly is to preserve her own liquidity if the fund closes. We examine the incentive to preserve liquidity in section III.B.

\section{III.B. The "Simple" MBR Rule: No Subordination}

Under what we call the simple MBR rule, redeeming shareholders' MBRs are not subordinated. Instead, as figure 3 shows, losses in excess of a fund's NAV-stabilizing buffer are allocated in proportion to shareholders' total MBRs, as long as the fund's losses do not exceed its buffer plus its aggregate MBR (for a 5 percent MBR rule, that loss threshold falls at 5.5 percent of the fund's preredemption assets). The figure depicts the losses of investors who redeem none, 25 percent, and all of their available shares 
Figure 3. Investor Losses with a Simple MBR Rule, When Others Do Not Redeem

Investor's loss (percent of preredemption holdings)

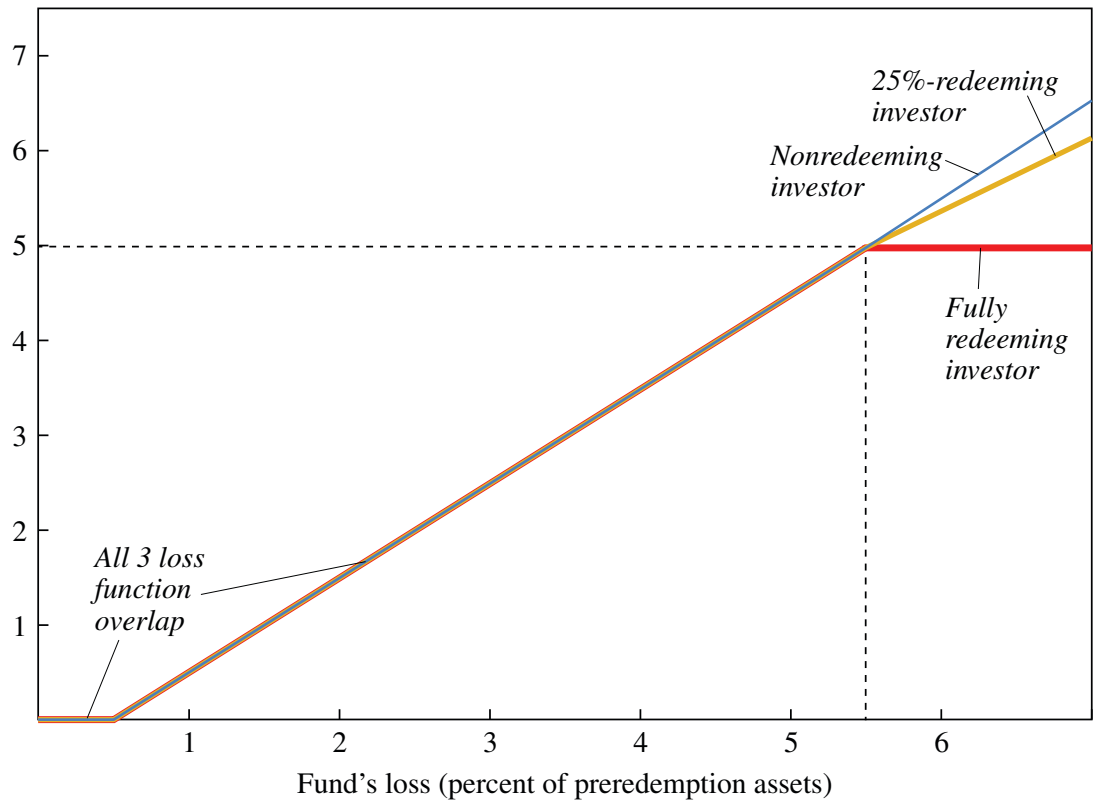

Source: Authors' model described in the text.

a. Under the simple MBR rule, losses in excess of any capital buffer (assumed here to be 0.5 percent) are allocated across all shareholders in proportion to their MBRs (assumed here to be 5 percent), as long as the fund's losses do not exceed 5.5 percent (its capital buffer plus its aggregate MBR). Losses beyond 5.5 percent are borne only by nonredeeming shareholders. As in figure 1, each investor's losses are shown under the assumption that redemptions by other investors are trivial.

in an MMF with a simple MBR rule. Whereas all of an investor's shares are available for redemption in the absence of an MBR, only 95 percent of each investor's reference amount is available with a 5 percent MBR.

The simple MBR rule is a notable improvement on the "status quo" (that is, a fund with just an NAV-stabilizing buffer). Because investors' varying redemptions do not immediately reduce their MBRs, the simple MBR rule ensures that all investors' loss functions lie atop one another-at least as long as the fund's losses are less than its buffer plus its aggregate MBR. Hence, the simple rule ameliorates the allocation of losses among investors and reduces incentives to redeem.

However, the simple rule has a very serious limitation: it only reduces the incentive to redeem shares in a troubled MMF; it does not eliminate that incentive. Even with the simple MBR rule, investors in a troubled 
MMF would have several good reasons to redeem. First, the fully redeeming investor limits his losses to his MBR; any losses in excess of a fund's buffer plus its aggregate MBR are shouldered exclusively by nonredeeming shareholders. In the stylized example in figure 3, once the fund's losses exceed 5.5 percent, nonredeeming shareholders' losses exceed those of redeeming shareholders. Hence, redeeming all MMF shares is beneficial if losses are large, and it does not make the investor worse off if losses are small. Second, redeeming investors still may be able to shift liquidityrelated costs arising from their own redemptions to other investors in the fund. These costs may be especially important during episodes of financial strain, when liquidity is likely to be at a premium.

Third, even with the MBR, shareholders have an incentive to redeem to safeguard their own liquidity, because those who do not redeem from an MMF that closes may lose access to their cash during a prolonged liquidation phase. Figure 4 illustrates this point under the simple assumption that shareholders would be indifferent between having their investments locked up in a closed MMF during a liquidation phase of indefinite duration and having to incur a 0.5 percent fee to obtain all of their assets immediately. ${ }^{19}$ The figure shows losses for investors both excluding (reproduced from figure 3) and including this opportunity cost of lost liquidity. The magnitude of this cost depends on whether the fund must close and the value of the investor's remaining shares in the fund if it does close. (If losses erode the value of an investor's shares in a closed fund, the value of his lost liquidity declines proportionally.)

The nonredeeming investor's loss function inclusive of liquidity cost jumps up at the point when losses exceed 0.5 percent, since at that point the fund must close and the investor's entire balance is locked up for the duration of the fund's liquidation process. Importantly, with a simple MBR rule, when liquidity costs are taken into account, any loss large enough to cause fund closure causes greater losses for nonredeeming than for redeeming investors. ${ }^{20}$ In this example the fully redeeming investor's liquidity loss is at most

19. In section IV.C we review empirical evidence suggesting that this assumption about the cost of lost access to MMF shares is not unreasonable (section 6.2 of our working paper discusses the evidence in more detail). But the qualitative points we make here are important as long as the liquidity cost is material to investors. Note that these liquidity costs to investors whose MMF shares are unavailable for an indefinite period after a fund's closure are distinct from the costs that a still-open fund may incur to liquidate assets to meet shareholders' redemptions.

20. This result does not depend on our assumption here that preservation of liquidity is worth 0.5 percent to investors; any nontrivial price for liquidity makes redeemers relatively better off. 
Figure 4. Investor Losses with a Simple MBR Rule and Liquidity Cost, When Others Do Not Redeem ${ }^{\mathrm{a}}$

Investor's loss (percent of preredemption holdings)

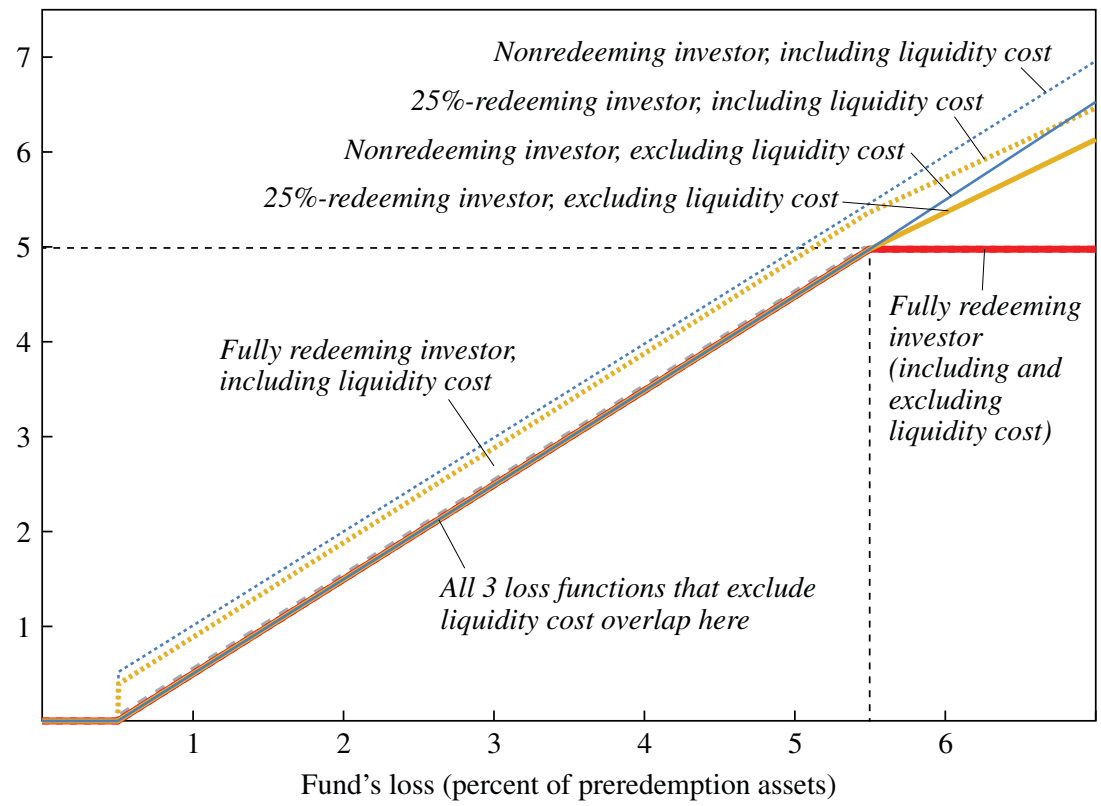

Source: Authors' model described in the text.

a. Losses are depicted here both without liquidity cost (as in figure 3) and with this cost. The liquidity cost is the cost to investors of having their shares locked up in a closed MMF during a liquidation phase of indefinite duration and is assumed to be 0.5 percent of the value of their remaining shares in the fund. The liquidity cost causes the losses of the nonredeeming investor to increase by 0.5 percent of the value of his holdings once the fund's losses exhaust its capital buffer and force it to close. The corresponding liquidity losses for the fully redeeming investor are limited to 0.5 percent of the value of her MBR. As in figure 1, each investor's losses are shown under the assumption that redemptions by other investors are trivial.

2.5 basis points ( 0.5 percent of 5 percent of assets), and it declines as the investor's MBR is absorbed. Hence, for this investor the line representing losses inclusive of liquidity cost lies just a bit above the line for losses exclusive of that cost when the MMF itself experiences losses of less than 5.5 percent.

This example illustrates some of the pros and cons of the simple MBR rule. This rule would reduce redeemers' first-mover advantage and allocate any losses that a fund might suffer more equally. Hence, it would have some benefit, for example, in protecting retail investors, who have proved to be much less likely to run than institutional investors. However, the simple rule leaves investors with strong incentives to run from distressed MMFs, since a redeeming investor incurs no additional cost but 
limits her losses to the size of her MBR, preserves her liquidity, and possibly imposes some liquidity costs on others. Nonredeeming shareholders would still be at greatest risk of suffering losses. Hence, the simple MBR rule does not eliminate the destabilizing allocation of risks and costs between redeeming and nonredeeming shareholders. Under such a rule, MMFs - particularly those with large institutional investors that may be highly motivated to preserve liquidity—still would be vulnerable to runs and constitute a source of systemic risk.

\section{III.C. The "Strong" MBR Rule: Adding Subordination}

The strong MBR rule addresses the shortcomings of the simple rule by subordinating the MBRs of redeeming investors to create a disincentive to redeem. As outlined in section II.B, the fraction of an investor's MBR that is subordinated would be equal to the fraction of her available balance that she has redeemed. Figure 5 shows the allocation of losses in a fund under the strong rule, again with the assumptions that all other redemptions from the fund are trivial and that liquidity costs due to losing access to shares in a closed fund are zero. (For simplicity, we do not incorporate the retail exemption discussed in section II.C.)

Under the strong rule, if the fund's losses are smaller than its buffer plus its aggregate MBR, the fully redeeming investor fares worse than the investor who redeems less or not at all. In this stark example, the fully redeeming investor loses her entire MBR for MMF losses just slightly larger than 0.5 percent, because other investors do not redeem anything. By redeeming her entire available balance, she has put her full MBR in a subordinated position, but without other redemptions, her MBR is the fund's total subordinated MBR. ${ }^{21}$ Importantly, however, the fully redeeming investor still is better off than others if the fund's losses exceed its buffer plus its aggregate MBR.

Figure 6 adds consideration of the potential liquidity costs for investors who may have their money locked up in a closed MMF through a pro-

21. In this example, because no other investor redeems, the redeeming investor is effectively leveraged by the ratio of the fund's assets to her assets when the fund's losses exceed its capital buffer, up to the point at which the redeeming investor's subordinated MBR is absorbed. This stark allocation of losses is admittedly an extreme example. Data from the Investment Company Institute (2012) show that monthly redemptions in MMFs from 2009 to 2011 averaged 45 percent of the funds' assets, so the likelihood that a 30-day period might pass in which only one or a few investors redeem shares seems remote. Notably, the retail exemption discussed in section II.C also would help ensure that small redemptions never lead to subordination of those investors' MBRs. 
Figure 5. Investor Losses with a Strong MBR Rule, When Others Do Not Redeem ${ }^{\mathrm{a}}$

Investor's loss (percent of preredemption holdings)

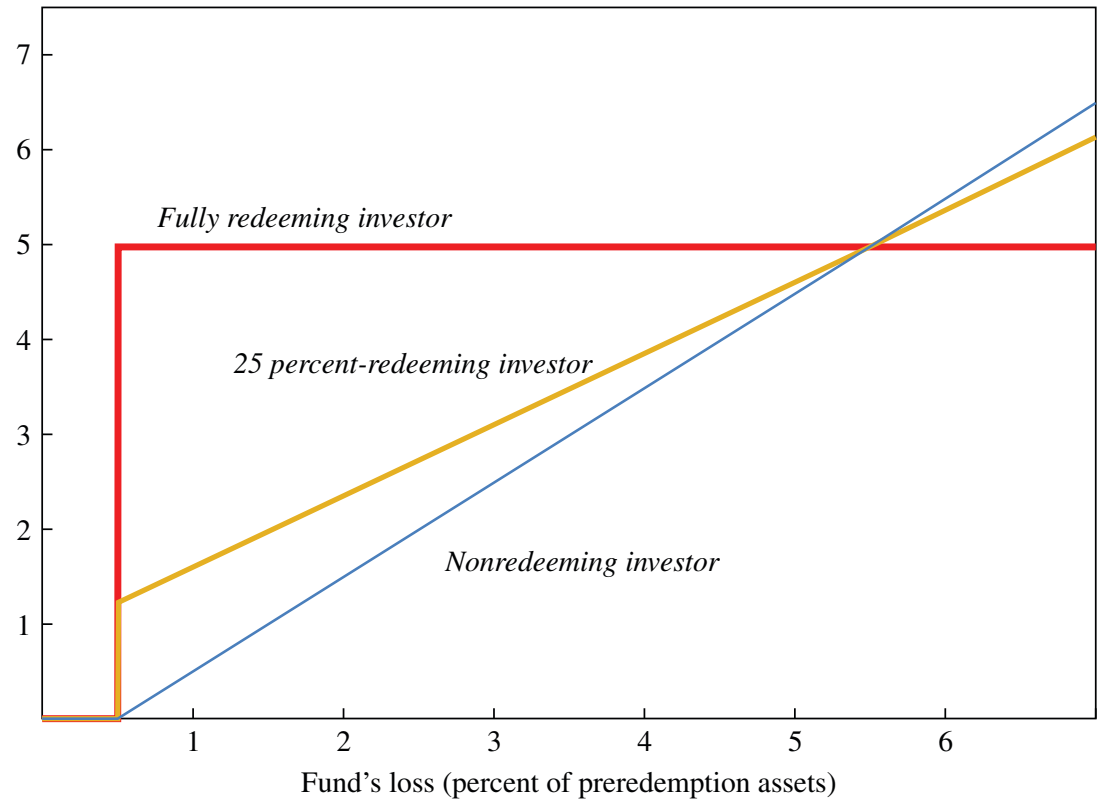

Source: Authors' model described in the text.

a. Under the strong MBR rule, the MBRs of redeeming investors are subordinated in proportion to their redemptions of their available balances. Any losses in excess of a capital buffer are allocated to the subordinated portions of those investors' MBRs, which must be exhausted before nonredeeming investors bear any loss. As in figure 1, each investor's losses are shown under the assumptions that redemptions by other investors are trivial and that liquidity costs are zero. With the strong MBR, redeeming investors face larger losses (excluding liquidity costs) than nonredeeming investors unless the fund's losses exceed its capital buffer plus its aggregate MBR - in that case, redeeming investors are better off.

longed liquidation process. The figure shows that even when these costs are taken into account, the strong rule can create a disincentive to redeem.

Figure 7 shows how a fully redeeming investor's losses depend on the behavior of other investors under a strong MBR rule (for simplicity, we again exclude the costs of lost liquidity). The fully redeeming investor's losses are less extreme for small losses to the fund when other investors redeem as well. That is, when other investors redeem shares, they also contribute to the fund's subordinated MBR, so each investor owns a smaller share of the aggregate subordinated MBR.22 At the same time,

22. Put differently, when many investors redeem, each redeeming investor's MBR is less highly leveraged than the MBR of a single redeeming investor if no one else redeems. 
Figure 6. Investor Losses with a Strong MBR Rule and Liquidity Cost, When Others Do Not Redeem ${ }^{\mathrm{a}}$

Investor's loss (percent of preredemption holdings)

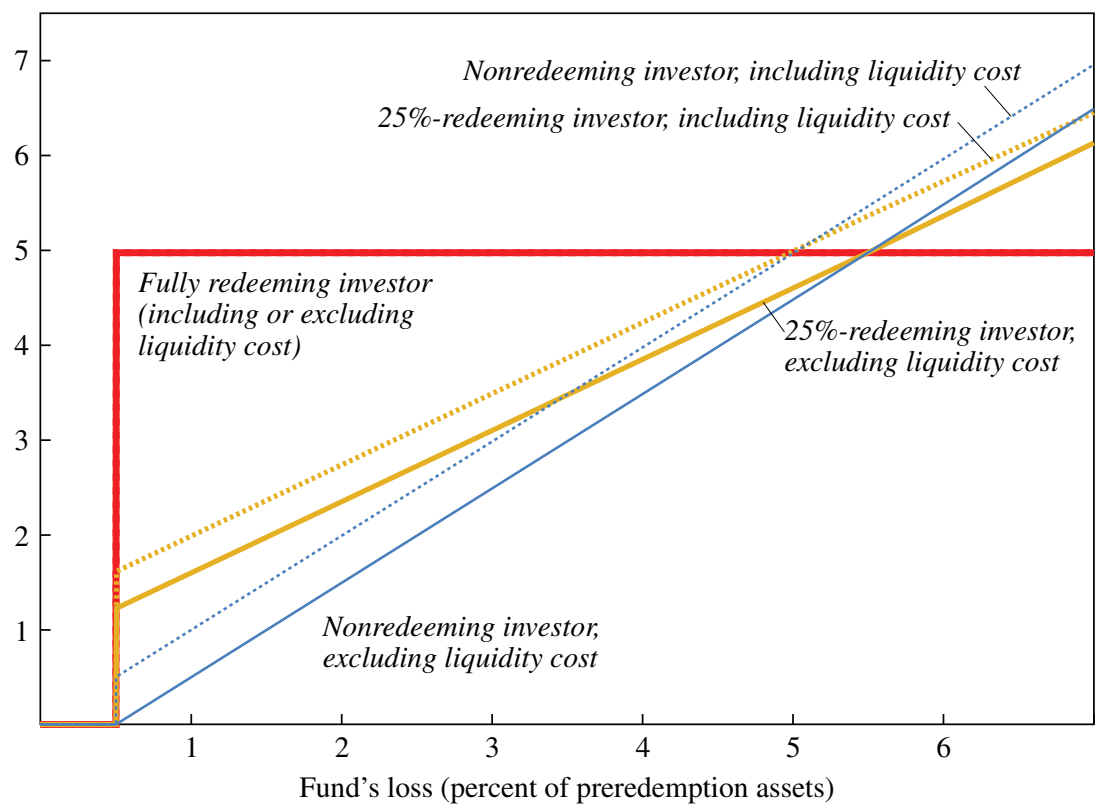

Source: Authors' model described in the text.

a. When redemptions by other investors are trivial, redeeming investors under the strong rule still bear the fund's losses in excess of any capital buffer until the subordinated portions of their MBRs are exhausted. However, nonredeeming investors also experience losses, in the form of liquidity costs, if the fund's losses exceed a capital buffer and force the fund to close. Liquidity costs are smaller for redeeming investors, who have fewer shares locked up in the fund. Hence, liquidity costs associated with fund closure reduce the advantages of staying invested in a distressed MMF with a strong MBR rule, but that rule still can create a disincentive to redeem.

\section{a nonredeeming investor's losses are also smaller when other investors redeem, because the subordinated MBRs of redeeming investors provide those who do not redeem some protection from losses. ${ }^{23}$}

23. Figure 7 can also be used to illustrate the effect of relaxing our assumption that all investors are small. Consider, for example, the case in which no other investor redeems. Then, the loss function of an investor who owns 25 percent of all outstanding shares in the fund and who redeems all of her shares is the same as for the small, fully redeeming investor when others redeem 25 percent. Because the larger investor owns a greater portion of the fund, the subordination creates less effective leverage for her MBR than it would for the MBR of a smaller investor (in the limit, the loss function of an investor who owns all the shares in a fund is unaffected by an MBR or subordination). The loss function for the larger investor, if she does not redeem, is the same as for the small, nonredeeming investor when others do not redeem. 
Figure 7. Investor Losses with a Strong MBR Rule, When Others Redeem ${ }^{\mathrm{a}}$

Investor's loss (percent of preredemption holdings)

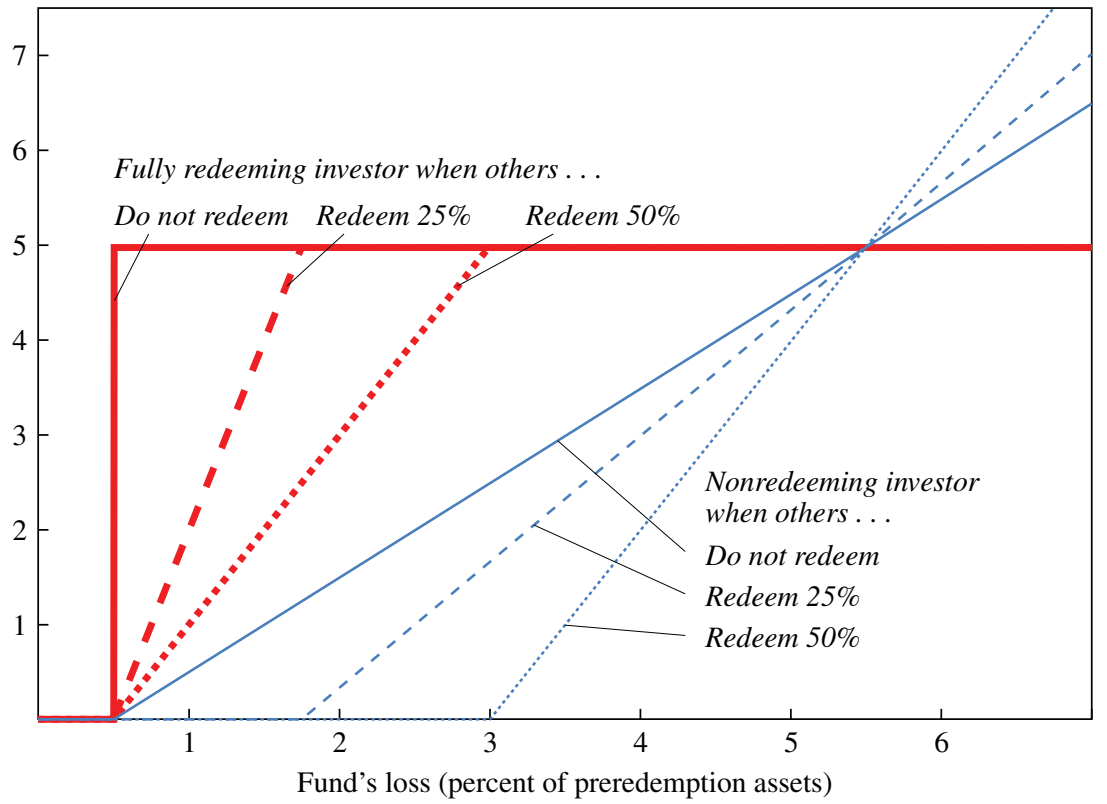

Source: Authors' model described in the text.

a. Under the strong MBR rule, both the fully redeeming investor and the nonredeeming investor see their losses diminish (rather than increase, as in figure 2) to the extent that other investors redeem, as long as the fund's losses do not exceed its capital buffer plus its aggregate MBR. This stabilizing effect of others' redemptions occurs because redeeming investors subordinate their MBRs and put them first in line to absorb losses after the fund's losses exceed any capital buffer. In this figure liquidity costs due to losing access to shares in a closed fund are assumed to be zero.

By making redemptions from a distressed MMF potentially costly, the strong MBR rule can help offset the incentives to redeem that arise from investors' preference for liquidity and the concern that losses might exceed a fund's capital buffer plus its aggregate MBR. The cost of redemptions also may offset the liquidation costs that redeemers impose on other investors. In addition, under this rule, redemptions protect nonredeeming investors by providing a subordinated buffer to absorb losses. In sum, the strong rule may offset and even reverse the incentive to redeem from a troubled fund, and thus may help stabilize a distressed MMF, allow it to weather a difficult period, and mitigate the externalities associated with a run.

The benefits of the strong rule are evident in a comparison of figures 2 and 7. Figure 2 shows that under current rules, an investor's losses depend on other investors' behavior in a destabilizing way. The more other 
investors are expected to redeem, the greater the expected losses for nonredeeming investors. This dynamic provides a strong incentive to redeem at the first sign of trouble, before others do. In contrast, figure 7 shows that with a strong MBR rule, an investor's losses depend on other investors' behavior in a stabilizing way. Redeeming investors contribute to the fund's subordinated MBR and provide more protection for nonredeeming investors. This dynamic stabilizes the fund and benefits retail investors and others who may not redeem quickly when MMFs encounter problems. Even so, it is important to recognize that if expected losses are large enough (or if the MBR is too small), investors may be better off if they redeem shares.

\section{Calibrating an MBR}

In this section we use empirical evidence to calibrate how large an MBR would need to be to reduce the vulnerability of MMFs to runs, and we provide some guidance on the appropriate delay for redeeming shareholders' MBRs. When an MMF encounters strains and the likelihood of losses increases, investors' decisions to redeem or not depend on how the choice affects their expected losses (including the value of lost liquidity) if the fund breaks the buck and closes. That is, for a fund in distress, conditional expectations are critical, and investors will redeem when doing so reduces their expected principal and liquidity losses in a break-thebuck scenario. ${ }^{24}$ Thus, as input for our calibration, we examine historical evidence on the size of MMF losses when they have occurred, including evidence from a novel and important data set on MMF losses in 2008. We also study the value of preserving liquidity in a crisis, which strengthens investors' incentive to redeem from a fund in distress. Finally, we examine evidence that can be helpful in setting the delay period for redemptions of investors' MBRs.

\section{IV.A. Previously Available Data on MMF Losses}

Although hundreds of MMFs have suffered material losses at various times over the last 30 years, information on the magnitude of those losses is not readily available. The historical record of losses in MMF portfolios has been obscured by fund sponsors' long-standing practice of providing discretionary financial support to MMFs that were in danger of breaking

24. These points are developed more formally in a simple model in section 4 of our working paper. Although our focus here is on investors' expected losses, we believe that the key insights of the section would be similar if we considered other moments of the loss distribution. 
the buck, even though such support is not required by either regulation or contract. SEC Chairman Schapiro reported in 2012 that sponsors had intervened more than 300 times to support MMFs since they were introduced in the 1970s (Schapiro 2012). Moody's found 144 cases from 1989 to 2003 in which U.S. MMFs received such support (Moody's Investors Service 2010). Steffanie Brady and others (2012) report 123 instances of support for 78 different money funds between 2007 and 2011. MMF sponsors reportedly intervened as recently as November 2011 to support their MMFs. ${ }^{25}$

We have no comprehensive data on the MMF losses that would have occurred in the absence of sponsor support. Sponsors are not required to disclose the value of their support for a distressed MMF at the time of an intervention, and available data generally do not provide enough information to estimate the magnitude of NAV declines that would have occurred without interventions. ${ }^{26}$

Still, the historical record and recent research provide some useful evidence. The two U.S. MMFs that have broken the buck since the adoption of rule 2a-7 in 1983 provide a couple of observations: the Community Bankers U.S. Government Money Market Fund lost 3.9 percent of its value in 1994 (U.S. SEC 1999), and the Reserve Primary Fund lost approximately 1.6 percent in 2008. ${ }^{27}$ Brady and others (2012) document $31 \mathrm{MMFs}$

25. Diana B. Henriques, "Money Funds Could Face More Changes," New York Times, January 7, 2012. www.nytimes.com/2012/01/08/business/mutfund/money-market-fundsmay-soon-face-more-changes.html?pagewanted=all\&_r=0.

26. The SEC's 2010 rule amendments for MMFs introduced new requirements for disclosure of support that should assist in estimating the value of such interventions. Even so, precise estimates of the real-time value of support actions are likely to remain elusive.

27. The Primary Fund's losses were caused largely by its $\$ 785$ million in holdings of Lehman debt obligations (1.3 percent of the fund's assets) at the time of Lehman's bankruptcy. RCMI, the adviser to the fund, announced at about $4 \mathrm{pm}$ on Tuesday, September 16, 2008, that the NAV of the fund's shares had dropped by 3 percent, to 97 cents, presumably because large redemptions had further eroded the NAV. However, a June 2009 court order regarding distribution of the Primary Fund's assets indicated that the value of those assets ultimately would allow shareholders to receive 98.4 cents per share, although this amount included income earned on the assets after the Primary Fund was closed. See the plaintiff's complaint in SEC v. Reserve Management Company, Docket no. 09-cv-4346, U.S. District Court for the Southern District of New York, May 5, 2009, p. 3, www.sec.gov/litigation/complaints/2009/ comp21025.pdf, and the court orderin the same case, June 8,2009, p. 35, www.sec.gov/spotlight/ reserve_primary_fund_investors/gardephe_order.pdf. Some statements by the fund's sponsor have referred to the portion of the fund's assets_-some of which lost significant valuethat have been returned to investors as part of the fund's liquidation process, rather than to investors' principal losses as claimants upon those assets. An example is the following, quoted in Anderson (2010) from a Reserve press release: "Including this seventh distribution, $\$ 50.7$ billion, or approximately $99.04 \%$ of Fund assets as of the close of business on September 15, 2008, will have been returned to investors." 
that between 2007 and 2011 received sponsor support that exceeded 0.5 percent of the fund's assets-enough, that is, that the support was probably required to prevent those funds from breaking the buck. Support was more than 2 percent of assets for 10 of these funds and exceeded 3 percent for 4 funds. ${ }^{28}$ Analysis by Moody's showed that at the time of Lehman's bankruptcy, 15 MMFs held Lehman obligations that ranged from 0.25 percent to 5.6 percent of fund assets and averaged 1.9 percenthence, the Reserve Primary Fund's position (1.3 percent) was less than the average among funds that held Lehman obligations at that time (Moody's Investors Service 2012c).

\section{IV.B. New Data on MMF Losses}

We analyze here a new data set that provides additional evidence on the scale of losses that have occurred in MMFs. The data come from the U.S. Department of the Treasury and the SEC, which collected information about certain MMFs that participated in the Treasury's Temporary Guarantee Program for Money Market Funds in 2008. MMFs with shadow NAVs below $\$ 0.9975$ were required to report information about their portfolios, including what their NAVs would have been without sponsor-provided guarantees, such as capital support agreements (U.S. Department of the Treasury 2008). Even so, the NAV data do not reflect the full extent of losses that might have occurred without sponsor interventions, since the effects of some types of sponsor support, such as direct cash infusions to a fund and outright purchases of securities from a fund at above-market prices, are not excluded from reported shadow NAVs. Of course, the data also do not reflect portfolio losses that might have occurred in the absence of extensive government support in 2008 for MMFs, short-term funding markets, and some financial institutions.

The Treasury-SEC data include the shadow NAVs of reporting MMFs (but not the funds' identities) from September 5 to October 17, 2008. ${ }^{29}$ As the first row of table 1 shows, 72 funds reported their shadow NAVs at some point over this period. The average of the minimum shadow NAVs reported by each of these funds during this period was $\$ 0.989$; that

28. In addition, Moody's (Moody's Investors Service 2010) found that between 2007 and 2010, 21 MMF sponsors spent at least $\$ 12.1$ billion to maintain stable NAVs for their funds, although that figure includes support for some European funds and some nonregistered investment pools. Moody's totals were not stated as shares of the supported funds' NAVs.

29. The Treasury's temporary guarantee program was announced on September 19, but some funds provided data for shadow NAVs on dates before the program's inception. 
Table 1. Minimum Shadow NAVs of Reporting Money Market Funds, September 5 to October $17,2008^{a}$

\begin{tabular}{lcc}
\hline & $\begin{array}{c}\text { No. of } \\
\text { MMFs }\end{array}$ & $\begin{array}{c}\text { Average minimum } \\
\text { reported shadow NAV } \\
\text { (dollars per share) }\end{array}$ \\
\hline All reporting MMFs & 72 & 0.989 \\
MMFs reporting a minimum shadow NAV under \$0.995 & 29 & 0.978 \\
MMFs reporting a minimum shadow NAV between & 26 & 0.985 \\
$\quad$ \$0.95 and \$0.995 & 1 & 0.903 \\
$\begin{array}{l}\text { Memorandum: Minimum reported shadow NAV for } \\
\text { any MMF }\end{array}$ & & \\
\hline
\end{tabular}

Sources: U.S. Department of the Treasury and U.S. Securities and Exchange Commission.

a. Reported shadow NAVs exclude the effects of guarantees from sponsors but may include the effects of some other forms of sponsor support, such as direct cash infusions to the fund or outright purchases of securities from the fund at above-market prices.

is, the average loss was $\$ 0.011$ per share (1.1 percent). The second row indicates that 29 funds reported shadow NAVs that would have fallen below $\$ 0.995$ — enough to break the buck - at some point during this episode. ${ }^{30}$ On average, these funds' shadow NAVs would have dropped to $\$ 0.978$ (a 2.2 percent loss) without sponsor support. Even when three outliers (funds that reported minimum shadow NAVs of $\$ 0.935, \$ 0.929$, and \$0.903) are excluded, the average shadow NAV of funds that would have broken the buck was $\$ 0.985$ (third row of table 1 ).

\section{IV.C. Liquidity Costs of Losing Access to Shares in a Closed MMF}

As discussed above, when an MMF breaks the buck and closes, its shareholders suddenly lose access to their cash for what may be a prolonged liquidation process. Indeed, the Reserve Primary Fund, which broke the buck on September 16, 2008, still had not completed the distribution of all assets to shareholders more than 3 years later (Schapiro 2012). Clearly, a fund's closure imposes a liquidity cost on its shareholders.

There are many challenges in estimating this cost and thus in assessing the strength of shareholders' incentives to redeem shares in a distressed fund to avoid lost liquidity. The opportunity cost to shareholders of an unplanned loss of access to cash could depend on a number of factors,

30. This total could exclude MMFs that received direct cash infusions from sponsors or benefited from sponsors' outright purchases of securities from the fund at abovemarket prices. 
including shareholders' individual circumstances, broader financial conditions, and the length of time over which access is lost.

We use several approaches to estimate the value of shareholders' lost liquidity (these are discussed in more detail in our working paper). One is to examine the average net cost to an investor who must take out a business loan from a bank to replace cash in a closed MMF. We show that this net cost (the rate on the bank loan less the yield on the investor's MMF shares until they are liquidated) averaged about 2 percent at an annual rate during the financial crisis. ${ }^{31}$ Liquidity premiums for financial instruments, particularly during periods of financial strain when investors most likely would be motivated to run from MMFs, provide another perspective on the costs of lost liquidity. Although these premiums are difficult to estimate, various methods discussed in our working paper suggest that premiums might range from 1 to 2 percent at an annual rate.

The cost of lost liquidity in a closed MMF also depends on the length of time over which investors are likely to lose access to their cash. Ideally, shareholders might expect to receive cash as the securities held by their fund mature, although payments of subordinated claims would have to wait until other claims have been paid. Among prime MMFs, which largely invest in the debt securities of private firms, the weighted-average life of portfolio holdings was 71 days in 2012, and the longest-dated nongovernment security in each fund's portfolio matured, on average, in 314 days. However, in practice, investors' wait might extend for years, as the Reserve Primary Fund example shows.

The evidence we have reviewed indicates that the opportunity costs of lost liquidity to investors in a closed MMF are probably significant. Assuming that investors expect to lose access to shares in a closed MMF for 6 months, we believe that an MBR should be designed to withstand redemption pressures that incorporate investors' incentives to avoid lost-liquidity costs of at least 0.5 percent of the value of their MMF shares.

\section{IV.D. How Large Should an MBR Be?}

To calibrate the size of an MBR sufficient to create a disincentive for investors to run from a distressed MMF, we draw on the empirical evidence on historical MMF losses described in sections IV.A and IV.B and assume that MMF losses are distributed exponentially, with an unconditional mean of 1.5 percent, so that losses conditional on a fund breaking the buck

31. Here we assume that the investor can take out such a loan. An investor who faces borrowing constraints presumably would have larger liquidity costs. 
(that is, when losses exceed 0.5 percent of assets) average 2 percent. ${ }^{32}$ On the basis of the evidence discussed in section IV.C, we also assume that the liquidity costs to an investor in an MMF that closes are 0.5 percent of the value of the shares that the investor cannot access. Finally, we assume that the fund has a small ( 0.5 percent $)$ capital buffer and that when it encounters distress, other investors do not redeem..$^{33}$

Figure 8 illustrates the calibration under these assumptions. Each line in the chart shows how an investor's expected losses vary with her own redemptions for an MBR of a given size. When the MBR is small-1 or 2 percent under our assumptions - these expected-loss curves slope downward, so investors reduce their expected losses by redeeming more shares. That is, if the MBR is too small, investors still have an incentive to run from a fund in distress. With an MBR of 3 percent, the expected-loss function slopes slightly upward, indicating that the investor would be better off not redeeming. MBRs of 4 or 5 percent provide more convincing disincentives to redeem. This exercise suggests that an MBR of 3 percent, combined with a small, NAV-stabilizing buffer, might be enough to protect MMFs from runs during a crisis. (In our working paper, we examine the calibration issue in more detail and conclude that an MBR of 3 to 4 percent might be needed.)

This exercise estimates only a minimum effective size for an MBR; the appropriate size in practice would depend on broader criteria. Most notably, the goal of internalizing the significant social costs of redemptions in a crisis suggests that the optimal slope for the investor's expected-loss function should be positive- that is, the investor should face expected redemption costs that incorporate the large externalities associated with runs from MMFs. ${ }^{34}$

32. Since we lack sufficient data to estimate reliably the density function of realized losses in the event that an MMF breaks the buck, we use the exponential distribution as a means of capturing the relatively high frequency of extreme returns in financial market data. Our aim is to calibrate an MBR of sufficient size to provide stability for the typical MMF in distress. The investor's decision to redeem or not must come before that loss is known, since a realized loss exceeding 0.5 percent would lead to the fund's closure and preclude further redemptions. Our calibration also assumes that the investor knows only that losses are drawn from the industry-wide distribution described here. More realistically, an investor in a given MMF would have information about the size of the fund's exposure to distressed assets and could base her decision on that more specific information.

33. Because other investors' redemptions can provide a protective (subordinated) buffer in an MMF with a strong MBR rule, the assumption that other investors do not redeem generally has relatively minor effects on our calibration. Section 6.3 of our working paper examines how changes in these assumptions affect our estimates of the appropriate size of the MBR.

34. For further discussion of these externalities, see FSOC (2012b), section VI. 
Figure 8. Expected Investor Losses under a Strong MBR Rule for MBRs of Varying Size

Investor's expected loss (percent of preredemption holdings)

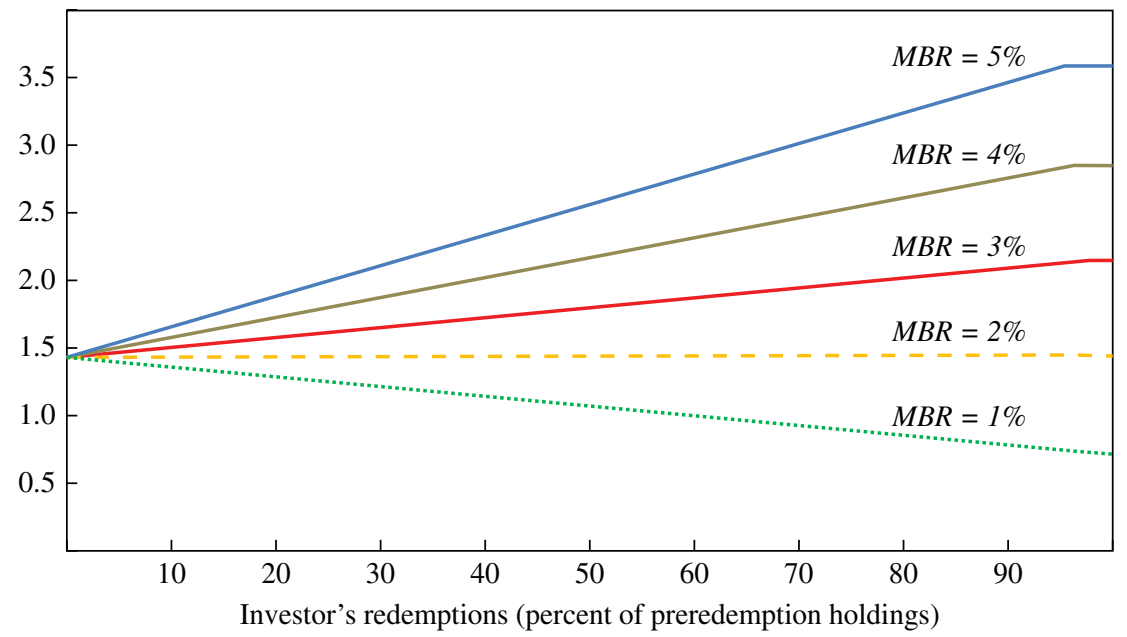

Source: Authors' calculations.

a. The calculation assumes that MMF losses are distributed exponentially, with an unconditional mean of 1.5 percent; that the fund has a 0.5 percent capital buffer; that investors' liquidity costs due to fund closure are 0.5 percent of the value of their remaining shares; and that other investors do not redeem. (Because other investors' redemptions can provide a protective buffer in an MMF with a strong MBR rule, the assumption that other investors do not redeem generally has relatively minor effects on this calibration.)

\section{IV.E. How Long a Delay for MBR Redemptions?}

To be effective in mitigating MMFs' vulnerability to runs, the delay period for redemptions of investors' MBRs must be long enough to inhibit "preemptive" runs. With very short delays, investors may expect that redeeming at the first sign of a problem will allow them to recover their MBRs before any losses are realized. Because this strategy would require an investor to exit a distressed fund earlier than he would under current rules, a short delay might make MMFs even more vulnerable to preemptive runs.

At the same time, delays should not be so long as to unnecessarily impose liquidity costs on shareholders or impede market discipline for MMFs. In particular, very long delays might inhibit investors from pulling away from a fund with poor management, even long before the emergence of any specific strains in its portfolio.

The events of September 2008 suggest that a very short delay, such as 1 week, would not be enough to prevent preemptive runs on MMFs. Even amid the run triggered by Lehman's bankruptcy early on Monday, 
September 15, every MMF except the Reserve Primary Fund managed to survive without breaking the buck until the end of the week, when the Treasury introduced its temporary guarantee program and removed concerns about losses. (As noted above, many funds avoided breaking the buck only because they received considerable discretionary sponsor support.) With an MBR delay of just a few days, an MMF shareholder who redeemed from a fund even after Lehman failed might have avoided any loss and shifted potential risks and losses to nonredeemers.

The maturities of MMF assets suggest an upper bound for the delay period. Because any problems in a fund's portfolio at the time of an investor's redemption should be resolved by the time the fund's longest-lived asset matures, the delay period might be as long as 397 days, the maturity limit for privately issued assets that MMFs can hold. On average, as noted above, a prime MMF's longest-dated security held in 2012 (excluding government securities) matured in 314 days. Although the 30-day delay that we suggest is relatively short in comparison, about half of prime MMFs' assets (on average) mature within 30 days, so a delay of that length should provide a reasonable amount of time to ensure that any problems with assets at the time an investor redeems are resolved before disbursement of her MBR.

Since MMFs must report on their websites detailed portfolio holdings data on a monthly basis, a 30-day delay means that an MMF usually would publish updated data at some point between an investor's request for redemption of her MBR and her receipt of payment. Hence, a 30-day delay would help ensure that investors who request redemptions based on information about a problem that has already occurred in an MMF's portfolio would not be paid before updated information about the portfolio is publicly released.

\section{Policy Considerations}

This section first explores how the MBR rule would compare with other proposals for MMF reform and then examines a number of practical issues that might affect the implementation, operation, and effectiveness of an MBR rule.

\section{V.A. How Would an MBR Rule Compare with Other Options for MMF Reform?}

As described in section I, advocates of MMF reform have focused on four basic approaches to reduce the funds' vulnerability to runs. Besides the MBR, the alternatives include requiring the funds to have floating NAVs, 
requiring them to have a capital buffer, and imposing fees or (non-MBR) restrictions on redemptions.

The risks that MMFs pose to the financial system are externalities: substantial social costs that redeeming MMF investors and other market participants currently do not bear. Hence, any reform should aim at internalizing these costs. Doing so, however, likely would cause a reduction in the equilibrium size of the industry, might drive up required returns for MMF investments, and could increase borrowing costs in short-term funding markets. ${ }^{35}$ For these reasons, all serious MMF reform options are unpopular with MMF shareholders, with the firms that offer MMFs, and with those that borrow from MMFs. Comments from market participants on the FSOC's proposed recommendations on MMF reform have overwhelmingly opposed all three of the alternatives put forth by the council. ${ }^{36}$

MMFs offer market-based yields that reflect the risk of the securities they hold, while at the same time offering principal stability and redemption on demand. This combination is inherently unstable, and all effective reform alternatives would diminish the attractiveness of MMFs by taking something off the table: capital buffers would diminish yields, a floating NAV would reduce principal stability, and any redemption restriction would limit liquidity (FSOC 2012b). The net benefits of reform will depend not only on the extent to which it succeeds in stabilizing MMFs, but also on how market participants respond. Reforms that drive institutional investors into lightly regulated or unregulated MMF substitutes may be less effective at improving systemic stability than alternatives that preserve some of the attractive features of today's MMFs. ${ }^{37}$ Although the focus in this paper is on the potential benefits of an MBR for money funds, the most effective reform strategy might be one that creates different types of MMFs with different risk mitigation features, so investors can choose the MMFs that best suit their preferences rather than move money to unregulated vehicles. For

35. Raising the cost of short-term borrowing could be a desirable outcome of reform, given that such borrowing itself may have negative externalities (see, for example, Brunnermeier and Oehmke 2013).

36. Comments on the FSOC's proposed recommendations can be found at www.regulations. gov/\#!docketBrowser;rpp=50;po=0; D=FSOC-2012-0003.

37. Less regulated substitutes for MMFs already exist and hold sizable portfolios. For example, data from iMoneyNet indicate that "offshore" MMFs that denominate their shares in dollars had about $\$ 400$ billion in assets under management at the end of 2012, and "enhanced cash" funds that rely on exemptions from the Investment Company Act to avoid MMF rules had about $\$ 200$ billion in assets in mid-2012. In general, such substitutes are available only to institutional investors. For more on potential shifts of assets to MMF substitutes, see U.S. SEC (2012). 
example, reforms might allow for funds with MBRs as well as funds that are exempt from MBR rules because they have substantial capital buffers or hold only Treasury securities.

A FLOATING-NAV REQUIREMENT A requirement that all MMFs have floating NAVs has considerable appeal among policymakers, academics, and others for its simplicity, elimination of NAV rounding, and potential to improve investors' understanding of MMF risks. A floating NAV would partially internalize the cost of redemptions by ensuring that investors who exit a fund that has incurred a loss do not receive $\$ 1$ per share. It would also make fluctuations in the value of an MMF portfolio more transparent in share prices, could help investors become more cognizant of MMF risks, and might reduce the ex ante incentives of portfolio managers to take risks, since those risks would result in greater (and more observable) share price volatility. ${ }^{38}$

However, unlike investors in MMFs with an MBR, investors in floatingNAV money funds would still have a strong incentive to redeem quickly during crises (FSOC 2012b, Hanson and others 2012, Gordon and Gandia 2013). As mentioned above, MMFs typically meet net redemptions by disposing of their more liquid assets, rather than by selling a cross section of all of their holdings. Such liquidity management practices help funds avoid realizing losses from sales of less liquid investments. But these practices essentially subsidize redeeming investors by leaving the remaining investors with claims on a less liquid portfolio. The subsidy may be immaterial in normal times, but during periods of market strain, when liquidity is at a premium, the incentive to redeem grows. Indeed, some empirical research suggests that floating-NAV money funds in Europe were as vulnerable to runs as stable-NAV funds during the financial crisis (Gordon and Gandia 2013), although other work finds that stable-NAV funds were indeed more vulnerable (Witmer 2012).

An additional concern is that implementing the floating-NAV option would be tantamount to "eviscerating" MMFs (Investment Company Institute 2009). Opponents of a floating NAV have cited several concerns about

38. A prerequisite for these benefits is that the share prices of MMFs actually fluctuate on a regular basis. Under current rules MMFs can round their share prices to the nearest cent, so any variations of less than 0.5 percent in the value of an MMF's portfolio are rounded away. The values of MMF portfolios typically vary only by a few hundredths of 1 percent, so share prices almost never vary. One proposal for floating NAVs would allow MMFs to maintain $\$ 10$ NAVs and round to the nearest cent, so variations of less than 0.05 percent still would be rounded away. That approach likely would preserve stable share prices and undermine the potential benefits of a floating NAV. 
its potential impacts on MMF investors, including tax and accounting complications that might substantially diminish the funds' appeal (see, for example, Investment Company Institute 2013). Because lightly regulated substitutes for MMFs would continue to offer stable NAVs, any reform that forced all MMFs to have floating NAVs might lead to a large migration of assets to these less regulated vehicles.

The floating-NAV option would offer additional flexibility to MMFs in an environment of very low interest rates. Some commentators have suggested that the easing of monetary policy could be constrained by concerns that very low interest rates might put MMFs out of business (see, for example, Sellon 2003, Keister 2011, Cœuré 2012) ${ }^{39}$ A money fund with a floating NAV might prove less vulnerable to low rates because it could charge expenses that exceed its earnings on portfolio securities without opening a gap between the share price and the underlying value of its shares. ${ }^{40}$

A CAPITAL BUFFER REQUIREMENT Like the MBR rule, capital creates a buffer to absorb potential MMF losses. Each approach has advantages and disadvantages.

A capital buffer would give MMFs some capacity to absorb losses without breaking the buck. This could allow the funds to operate without disruption even after suffering material losses and could eliminate the possibility of dilutive redemptions. An MBR, in contrast, would not prevent funds that suffer losses from breaking the buck.

A substantial capital buffer-one comparable in magnitude to the MBR that we recommend - could have two additional advantages over an MBR rule. First, capital might allow a more efficient allocation of risk among investors. Presumably the owners of the capital would have greater tolerance for risk than investors in a stable-NAV money fund (Hanson and others 2012). An MBR primarily would clarify the allocation of risks among

39. The sources cited here mention only that MMFs may be seen as an impediment to easing of policy; they do not focus in detail on those concerns.

40. MMFs pay their expenses (for example, for managing portfolios, processing transactions, and maintaining shareholder account data) out of the yields they earn on portfolio securities. Under current practices a fund that maintains a stable NAV and charges expenses that exceed portfolio yields would experience a destabilizing decline in the underlying value of its shares. MMFs have avoided this option, so the very low interest rates that have prevailed in recent years have diminished the revenue that MMFs can feasibly earn. Recently, however, stable-NAV money funds have explored novel options for handling low or even negative rates on short-term instruments. For example, euro-denominated funds have announced plans to pay expenses by decreasing the number of shares that investors own, rather than charging fees that reduce the value of those shares (see Moody's Investors Service 2012a, 2012b). 
MMF investors, although it is possible that MMF investors would contract with more risk-tolerant third parties to bear the risk of an MBR. Second, a substantial capital buffer could help curtail the MMF industry's historical reliance on voluntary sponsor support, which poses considerable systemic risk (McCabe 2010, PWG 2010, FSOC 2012b). However, a capital buffer that is too small to absorb reasonably foreseeable losses would not offer these advantages.

Some disadvantages of a capital buffer arise from the challenges of raising the large sums that would be needed. As of the end of 2012, each percentage point of capital as a share of industry-wide MMF assets would have required more than $\$ 25$ billion in funding, depending on the scope of the capital requirement (for example, whether it applied to MMFs investing only in Treasury securities). At least three possible funding sources have been suggested. First, MMFs might retain income that normally would be distributed to shareholders (see, for example, Goebel and others 2011). However, this process would require many years to build a substantial buffer unless the net yields paid to investors are reduced very sharply, and the incentives to protect the buffer would be unclear. Second, a buffer might be raised from third-party investors in capital markets (see, for example, BlackRock 2011, Hanson and others 2012). This would facilitate an efficient allocation of MMF risks by shifting them to investors who are more willing and able to take risks. However, it would require the creation of a market for a new, untested type of security and might entail significant underwriting and other costs. Third, a buffer could be financed by the MMF sponsors themselves (see, for example, BlackRock 2010). Although this approach would be simpler than obtaining funding in the capital markets, it could lead to further consolidation of the MMF industry among the affiliates of large, systemically important financial institutions. Hence, sponsor-funded capital could further concentrate systemic risks.

One clear advantage of a strong MBR over a capital buffer is that subordination creates a disincentive to run. Indeed, with such an MBR, investors can be better off not redeeming, even if they recognize that a fund's losses might exceed the size of its aggregate MBR. In contrast, capital only reduces the incentive to run from a fund at risk: investors still would have good reason to exit if the danger exists that losses might exceed the capital buffer. Thus, an MBR might do more to mitigate the vulnerability of MMFs to runs than a capital buffer of the same size.

A capital buffer and an MBR rule also would have different implications for investor incentives. By shielding MMF investors from some 
losses, a meaningful capital buffer would shift the incentives for ex ante risk management from the MMF's shareholders to the owners of the capital buffer, who might be well suited to this task (Hanson and others 2012) ${ }^{41}$ But an MBR should improve ex ante risk management as well, because an MBR would be, in effect, a buffer provided by the MMF shareholders themselves. By removing investors' option to redeem shares quickly when losses appear imminent, an MBR rule would strengthen shareholders' incentives to monitor the funds' risk taking well before problems materialize.

Both the MBR and a capital buffer might reduce shareholder demand for MMFs, but for different reasons. The costs of the capital buffer presumably would be funded in the same way as other MMF expenses and hence would reduce the net yields that MMFs pay to investors. The MBR, in contrast, would reduce the liquidity of MMF shares.

Because the strengths of a capital buffer and an MBR rule complement one another, we suggest that an MBR would be particularly effective if paired with a capital buffer. The MBR could bolster a capital buffer by creating a disincentive to redeem from an MMF in distress; this would lower the likelihood that capital might be eroded by redemption-driven fire sales of assets. A more substantial capital buffer could help reduce the importance of voluntary sponsor support for MMFs and make funds more resilient to losses. But even a small buffer could provide a means to eliminate dilutive redemptions. Notably, Alternative Two of the FSOC's proposed recommendations on MMF reform includes an MBR in tandem with a small capital buffer (FSOC 2012b).

REDEMPTION FEES AND NON-MBR RESTRICTIONS An MBR, if implemented, would be in place at all times. Proposals for other types of restrictions or fees for redemptions that are always in place appear less promising. For

41. The effect of capital on ex ante risk mitigation would depend on how the capital is financed. If capital were raised by creating a subordinated class of shares, the investors who purchased those shares would face strengthened incentives to monitor risks (BlackRock 2011, Hanson and others 2012). In contrast, if a small buffer were raised by retaining a portion of the fund's own income over many years (as proposed by Goebel and others 2011), the effect on incentives for monitoring risks is less clear. A sponsor-provided capital buffer presumably would reduce incentives for risk taking, although the considerable record of sponsors already providing implicit support ("ex post" capital) for their money funds clearly does not provide incentives adequate to prevent MMFs from taking risks that pose threats to financial stability. 
example, although a delay in disbursement of all redemptions would provide some extra time for an MMF to raise cash to meet heavy redemptions in a crisis, it would not reduce investors' incentive to redeem, nor would it halt the dynamics of a run. Moreover, imposition of a significant delay on all redemptions would eliminate much of the utility of MMFs for cash management. A fee on all redemptions would be an even more substantial departure from principal stability than a floating NAV, since investors would lose money on every redemption.

Conditional fees or restrictions for redemptions - that is, fees or restrictions that are not always in place-have garnered significant support from the MMF industry as an alternative to other options (see, for example, HSBC Global Asset Management 2011, BlackRock 2012, Investment Company Institute 2013). Such "standby" arrangements would allow MMFs to function much as they currently do in normal times but would halt or penalize redemptions when MMFs are under strain. For example, recent proposals would "gate" (that is, halt) redemptions if a fund's liquid assets fell below a threshold and then would charge a fee for any redemptions until the fund's liquidity was restored.

Conditional fees and restrictions might actually increase the risk of preemptive runs on MMFs in distress and speed up the spread of runs to other funds. The possibility that fees or gates might be imposed would heighten investors' incentives to redeem quickly from troubled MMFs, especially if they suspect that other investors will do so (FSOC 2012b, Hanson and others 2012). In contrast to running from a distressed MMF with a strong MBR rule, exiting an MMF with conditional fees or restrictions immediately before they are imposed would be essentially costless to the redeeming investor. In addition, given the similarity of MMF portfolios, news that one fund has halted redemptions could spark runs on other funds (Rosengren 2013).

\section{V.B. Some Practical Issues for MBR Implementation}

Although the focus of this paper is on the conceptual rationale for an MBR, we discuss here some practical policy issues to help illustrate how an MBR might be introduced. We also address some concerns that have been raised about the effectiveness of an MBR.

SHOULD ALL MONEY FUNDS HAVE AN MBR? A number of commenters on the FSOC's proposed recommendations for MMFs have suggested that reforms for money funds should focus exclusively on prime MMFs, which, as noted above, largely hold private debt securities (see, for example, 
Investment Company Institute 2013, Rosengren 2013)..$^{42}$ Prime funds do appear to pose the most direct threats to financial stability. These funds mostly provide financing to large global financial institutions (Scharfstein 2012, Hanson and others 2012), and the run in 2008 was focused on these funds.

Other types of MMFs also may be vulnerable to runs, however. The portfolios of government and tax-exempt MMFs have credit and interest rate risks, and each type has experienced strains in recent years. ${ }^{43}$ Nonetheless, the top priority for MMF reform probably should be shoring up prime funds. Indeed, the FSOC's Alternative Two, which includes an MBR, would exempt from the MBR requirement any MMFs that invest primarily in Treasury securities (FSOC 2012b). ${ }^{44}$

WHAT OTHER ADJUSTMENTS TO SUBORDINATION RULES MIGHT BE POSSIBLE? As noted in section II.C, the flexibility of the MBR concept allows a variety of adjustments, such as an exemption of the first $\$ 50,000$ of redemptions from triggering subordination. Another adjustment would cap the amount of an investor's balance that could be subordinated at a fraction of her MBR. This adjustment could limit potentially extreme outcomes if only a few investors redeem shares from a troubled MMF, and although it would reduce the effectiveness of an MBR of a given size, the MBR itself could be increased to offset the subordination limit. ${ }^{45}$

42. Prime MMFs accounted for 58 percent of the industry's assets at the end of 2012. Two other types of MMFs account for the rest: government MMFs generally hold securities issued by the U.S. Treasury, federal agencies, and government-sponsored enterprises such as Freddie Mac and Fannie Mae, as well as repos backed by such securities; and tax-exempt MMFs hold municipal securities.

43. Tax-exempt MMFs, especially those sold to institutional investors, also experienced substantial outflows in September 2008, but the magnitude of the decline was far smaller than that for prime MMFs. (Weekly data from the Investment Company Institute indicate that assets in institutional tax-exempt MMFs fell 12 percent from September 10 to October 1, 2008, while assets of institutional prime funds plummeted 29 percent in the same period.) Government MMFs also have experienced strains at times: one such fund operated by Reserve experienced very heavy redemptions in 2008 , and many government funds had heavy outflows in the summer of 2011 amid concerns about the federal debt ceiling impasse (FSOC 2012b).

44. Alternatively, the size of the MBR could depend on the composition of the fund's portfolio. Both the FSOC's proposed recommendations and Hanson and others (2012) suggest such an approach in determining the required size of a capital buffer.

45. In our working paper we call this adjustment the "effective MBR rule." We show that an effective rule that caps subordination at 40 percent of the MBR, in combination with an MBR of 5 percent, would achieve about the same degree of stability as a strong MBR rule (one that allows all of the MBR to be subordinated) and an MBR of 3 percent. 
WOULD AN MBR REALLY STOP RUNS BY PANICKED INVESTORS? Some critics of an MBR rule have suggested that investors will redeem shares from MMFs in a crisis, regardless of the incentives created by subordination (see, for example, BlackRock 2012, Investment Company Institute 2013). To be sure, accurate predictions of investors' behaviors in a crisis are difficult. Nonetheless, an MBR rule could reverse pressures on rational investors to exit MMFs during crises. In the event that some investors run regardless of incentives, the rules that we propose would help ensure that they bear the costs of their actions and would provide extra protections for other investors, so that staying invested in the fund could be a rational decision.

COULD INVESTORS "BROKER" THEIR ACCOUNTS TO TAKE ADVANTAGE OF A $\$ 50,000$ EXEMPTION FOR SUBORDINATION? In principle, investors could divide their large cash holdings into separate $\$ 50,000$ accounts at different MMFs for this purpose, but the effectiveness of such a strategy likely would be quite limited for large institutional investors. One indicator of the magnitude of the account balances in institutional MMFs is their requirements for minimum initial investments, which averaged \$18 million as of March 2013 for institutional prime funds with assets over $\$ 1$ billion. ${ }^{46}$ At the end of 2012, there were 241 prime MMFs, based on their filings of form N-MFP with the SEC. Thus, even if large institutional MMFs dropped their minimum investment requirements and a shareholder with an $\$ 18$ million balance spread it evenly across all funds in the industry, she still would have more than $\$ 50,000$ in each fund.

OMNIBUS ACCOUNTS AND IMPEDIMENTS TO IDENTIFYING INDIVIDUAL SHAREHOLDERS A more challenging obstacle to the functioning of an MBR is the use of omnibus accounts by intermediaries (such as broker-dealers) that sell MMF shares. An omnibus account is an aggregated account for multiple customers, and MMFs may have access to information about these accounts only at the aggregated level. An MBR rule applied only at the account level could be counterproductive. For example, even with a 5 percent MBR, a broker-dealer that has two customers with $\$ 100$ accounts and hence a $\$ 200$ omnibus account with an MMF could allow one customer to redeem all of his shares. The second customer would effectively face a 10 percent MBR.

46. Funds with assets greater than $\$ 1$ billion accounted for over 80 percent of institutional prime MMF assets. Data on minimum initial investments are from iMoneyNet. 
To address this issue in its proposed recommendations on MMFs, the FSOC noted that

MMFs would be required to apply the MBR requirement to each of their recordholders. This would include recordholders that are financial intermediaries, such as banks or broker-dealers that hold shares on behalf of their customers, unless the intermediaries provide the MMF sufficient information to apply the MBR requirement to the intermediaries' individual customers directly. Absent such information, an MMF and its financial intermediary recordholders would allocate between themselves the responsibility (and associated costs) of applying the MBR requirement equitably. (FSOC 2012b, p. 44)

However, the lack of transparency associated with omnibus accounts has undesirable effects that go well beyond the difficulties it creates for administering an MBR. Omnibus accounts, for example, played a role in facilitating a widespread abusive-trading scandal that roiled the mutual fund industry in $2003 .{ }^{47}$ Hence, there are good reasons to consider rule changes requiring that MMFs have better information about their actual shareholders, which also would allow more effective application of MBR rules.

\section{Conclusion}

This paper has described a new proposal, the minimum balance at risk, to mitigate the vulnerability of money market funds to runs. The MBR would be a small fraction of each MMF shareholder's recent balances that is subject to a 30-day redemption delay. An MBR would diminish or eliminate the advantages enjoyed by shareholders who redeem quickly, before others do, when an MMF is in distress, by ensuring that redeeming investors are not able to shift risks and losses to those who remain invested. By discouraging redemptions during crises, an MBR also would help prevent the destabilizing and costly dynamics of a run and the strains that MMF runs can propagate throughout the financial system. Thus, an MBR not only would benefit MMFs and their investors, but also would mitigate externalities associated with these funds.

A key element of our proposal is that a portion of redeeming investors' MBRs would be subordinated, to provide a deterrent to running from an MMF to avoid imminent losses. The disincentive to redeem would be

47. For example, the SEC found in 2005 that "one of the biggest obstacles to preventing short-term trading is the existence of omnibus account platforms" (U.S. SEC 2005, p. 49) and that "a number of the market timing abuses identified through our investigations reveal that certain shareholders were concealing abusive market timing trades through omnibus accounts" (U.S. SEC 2005, pp. 6-7). 
negligible in normal times but would become salient on the rare occasions when investors grow concerned about the risk of losses. When that risk is high, the MBR would create a trade-off for investors, who could either redeem shares to maintain their own liquidity or stay invested in the fund to safeguard their principal. In contrast, under current rules, investors who redeem from a troubled MMF preserve both liquidity and principal, while those who remain behind are put at greater risk of losing both.

An MBR offers some important advantages over other proposals for reducing the vulnerability of MMFs to runs. Importantly, it could allow MMFs to maintain features that are central to their attractiveness to investors, in particular their stable $\$ 1 \mathrm{NAVs}$, their market-based yields, and the immediate liquidity of the vast majority of each investor's balance. An MBR would not require MMFs to raise the large sums of capital needed to create a meaningful capital buffer, and thus likely would be more feasible than a stand-alone capital option (although a capital buffer could complement an MBR rule well). Moreover, an MBR rule would create a deterrent to redeeming in times of stress-one that neither a floating NAV nor a capital buffer can provide. And unlike some proposals for conditional ("standby") restrictions or fees on redemptions, an MBR would not set up incentives for preemptive runs. Indeed, an MBR likely would improve market discipline for MMFs by strengthening investors' incentives to monitor and respond to MMF risks when they first arise, rather than wait to redeem until serious problems are imminent.

On the basis of historical data on MMF losses, including a novel data set from the Treasury and the SEC on losses suffered by MMFs in 2008, we have gauged the size of an MBR that would be needed to protect MMFs from runs. Our analysis also incorporates evidence about the value of preserving liquidity in a crisis, which strengthens investors' incentives to redeem. We find that, for an MMF with a 0.5 percent capital buffer, an MBR of at least 3 to 4 percent probably would be adequate to create disincentives for redemptions. ${ }^{48}$

The run on MMFs in September 2008 underscored that these funds' structural vulnerabilities can have potentially deleterious consequences for the entire financial system. In addition, the 2008 run may have made funds' institutional investors more skittish and thus more prone to run. Heavy

48. Section 6 of our working paper provides more details of that analysis, including sensitivity analyses to address the uncertainties of estimating expected losses in a distressed MMF and the challenges of pinpointing liquidity costs to investors who lose access to shares in a closed fund. 
redemptions by institutional investors during the summer of 2011, partly in response to increasing concerns about the funds' European holdings, indicate that institutional investors are more responsive to the risks in MMFs than they were before $2008 .^{49}$ But policymakers have fewer tools to address MMF runs now than during the financial crisis, particularly because the Treasury's temporary guarantee program, which was instrumental in stopping the 2008 run, is no longer possible under current law.

In this environment the need for MMF reform is particularly salient. Fortunately, there may be near-term opportunities for implementing meaningful reforms. The Financial Stability Oversight Council's proposed recommendations to the SEC, which were published in November 2012, include an alternative featuring an MBR requirement for MMFs. The SEC in June 2013 proposed two options for MMF reform for public comment: a floating NAV for institutional prime MMFs and a requirement that funds impose or consider fees and restrictions for redemptions if their liquid assets fall below a threshold (U.S. SEC 2013). Thus, careful consideration of MMF reform options is timely and potentially very useful to policymakers. We believe that the MBR is a particularly promising option, offering a means of preserving the key features that make MMFs attractive to investors while providing MMFs with the stability needed to ensure that they continue to play an important role in the U.S. financial system, even in the event of another systemic crisis.

ACKNOWLEDGMENTS We thank the editors for many helpful comments. We are also grateful to Ken Anadu, Steffanie Brady, Wendy Lai-Ching Chan, Darrell Duffie, Matt Eichner, Josh Gallin, Jamie McAndrews, Susan McLaughlin, Eric Rosengren, Nathan Yeung, and seminar participants at the Federal Reserve Bank of New York, the Federal Reserve Bank of Boston, and the Board of Governors of the Federal Reserve System for comments on earlier versions of this paper, and we thank Greg Nini, Henry Shilling, and Sarah ten Siethoff for help in providing and interpreting data. The views expressed herein are those of the authors and do not necessarily reflect the view of the Board of Governors, the Federal Reserve Bank of New York, or the Federal Reserve System.

49. The outflows in 2011 occurred despite the fact that the European exposures caused no losses for MMFs (see FSOC 2012b, Chernenko and Sunderam 2013). In contrast, in August 2007, as the asset-backed commercial paper (ABCP) crisis unfolded and many MMFs suffered substantial losses due to holdings of distressed $\mathrm{ABCP}$, institutional investors generally did not redeem MMF shares (McCabe 2010). 


\section{References}

Anderson, Neil. 2010. "Less Than One Percent of Primary's Assets Are Still in Reserve." TheMutualFundWire.com (16 July). www.mfwire.com/article.asp? storyID $=32827 \&$ template $=$ article $\& b h c p=1$.

BlackRock. 2010. "ViewPoint: Money Market Funds. A Proposal for a Capitalized Special Purpose Entity.” New York (February 7). https://www2.blackrock.com/ webcore/litService/search/getDocument.seam?venue=PUB_IND\&source=GL OBAL\& contentId=1111124986.

2011. "Money Market Funds: Potential Capital Solutions." New York (August). https://www2.blackrock.com/webcore/litService/search/getDocument. seam? venue $=$ PUB_IND\&source $=$ GLOBAL\&contentId $=1111146889$.

. 2012. "Money Market Funds: A Path Forward." New York (September 27). https://www2.blackrock.com/webcore/litService/search/getDocument.seam? venue $=$ PUB_IND\&source $=$ GLOBAL\&contentId $=1111173537$.

Board of Governors of the Federal Reserve System. 2009. "Monetary Policy Report to the Congress." Washington (24 February). www.federalreserve.gov/ monetarypolicy/mpr_20090224_part2.htm.

Brady, Steffanie A., Ken E. Anadu, and Nathaniel R. Cooper. 2012. "The Stability of Prime Money Market Mutual Funds: Sponsor Support from 2007 to 2011." Risk and Policy Analysis Unit Working Paper no. 12-3. Federal Reserve Bank of Boston (August 13). www.bos.frb.org/bankinfo/qau/wp/2012/qau1203.pdf.

Brunnermeier, Markus K., and Martin Oehmke. 2013. "The Maturity Rat Race." Journal of Finance 68, no. 2: 483-521.

Chernenko, Sergey, and Adi Sunderam. 2013. "Frictions in Shadow Banking: Evidence from the Lending Behavior of Money Market Funds." Ohio State University and Harvard Business School (February 2). www.people.hbs.edu/ asunderam/mmf_2013-02-02.pdf.

Cœuré, Benoît. 2012. "Central Banks and the Challenges of the Zero Lower Bound." Remarks at the Meeting on the Financial Crisis, hosted by the Initiative on Global Markets at the University of Chicago Booth School of Business (February 19). www.ecb.int/press/key/date/2012/html/sp120219.en.html.

Federal Open Market Committee. 2008. "Minutes of the Federal Open Market Committee." Washington (October 28-29). www.federalreserve.gov/monetary policy/files/fomcminutes20081029.pdf.

Financial Stability Oversight Council (FSOC). 2011. Annual Report. Washington. www.treasury.gov/initiatives/fsoc/documents/FSOCAR2011.pdf.

2012a. Annual Report. Washington. www.treasury.gov/initiatives/fsoc/ Documents/2012\%20Annual\%20Report.pdf.

2012b. "Proposed Recommendations Regarding Money Market Mutual Fund Reform." Federal Register 77, no. 223: 69455 (November 19). www. gpo.gov/fdsys/pkg/FR-2012-11-19/pdf/2012-28041.pdf.

Goebel, Scott C., Carrie E. Dwyer, and C. David Messman. 2011. Fidelity, Charles Schwab, and Wells Fargo comment letter to the Securities and Exchange 
Commission regarding File No. 4-619, Release No. IC-29497, President's Working Group Report on Money Market Fund Reform (May 3). www.sec.gov/ comments/4-619/4619-97.pdf.

Gordon, Jeffrey N., and Christopher M. Gandia. 2013. "Money Market Fund Risk: Will Floating Net Asset Value Fix the Problem?" Columbia University School of Law Center for Law and Economic Studies Working Paper no. 426 (March).

Group of Thirty. 2009. Financial Reform: A Framework for Financial Stability. Washington (January 15).www.group30.org/images/PDF/Financial_Reform-A_ Framework_for_Financial_Stability.pdf.

Hanson, Samuel G., David S. Scharfstein, and Adi Sunderam. 2012. "An Evaluation of Money Market Fund Reform Proposals." Comment letter regarding Financial Stability Oversight Council, "Proposed Recommendations Regarding Money Market Mutual Fund Reform” (December 20). www.regulations.gov/\#! documentDetail;D=FSOC-2012-0003-0032.

HSBC Global Asset Management. 2011. "Liquidity Fees: A Proposal to Reform Money Market Funds." (November 3).

Investment Company Institute. 2009. "Report of the Money Market Working Group." Washington (March 17). www.ici.org/pdf/ppr_09_mmwg.pdf.

_. 2012. Investment Company Fact Book. Washington. www.ici.org/pdf/2012_ factbook.pdf.

2013. Comment letter of the Investment Company Institute regarding Financial Stability Oversight Council, "Proposed Recommendations Regarding Money Market Mutual Fund Reform" (January 24). www.regulations.gov/\#! documentDetail;D=FSOC-2012-0003-0071.

Keister, Todd. 2011. "Why Is There a 'Zero Lower Bound' on Interest Rates?" Liberty Street Economics blog (November 16). libertystreeteconomics.new yorkfed.org/2011/11/why-is-there-a-zero-lower-bound-on-interest-rates.html.

Lacker, Jeffrey M. 2011. Comment letter to the Securities and Exchange Commission regarding File No. 4-619, Release No. IC-29497, President's Working Group Report on Money Market Fund Reform (January 10). www.sec.gov/ comments/4-619/4619-54.pdf.

McCabe, Patrick E. 2010. "The Cross Section of Money Market Fund Risks and Financial Crises." Federal Reserve Board Finance and Economics Discussion Series Working Paper no. 2010-51 (September 12). www.federalreserve.gov/ pubs/feds/2010/201051/201051pap.pdf.

Mendelson, Simon, and Richard Hoerner. 2011. BlackRock comment letter to the Securities and Exchange Commission regarding Release No. IC-29497, File No. 4-619 (January 10). www.sec.gov/comments/4-619/4619-22.pdf.

Moody's Investors Service. 2010. "Sponsor Support Key to Money Market Funds." New York (August 8).

—. 2012a. "Frequently Asked Questions: Impact of Negative Yields on Money Market Funds.” New York (October 15).

. 2012b. "JPMorgan Liquidity Funds: Launch of Share Class Aims to Manage Low/Negative Yields.” New York (November 16). 
2012c. "Lehman Support in Prime Money Market Funds." New York (April 30).

President's Working Group on Financial Markets (PWG). 2010. "Report of the President's Working Group on Financial Markets: Money Market Fund Reform Options."Washington (October). www.treasury.gov/press-center/press-releases/ Documents/10.21\%20PWG\%20Report\%20Final.pdf.

Rosengren, Eric S. 2012. "Money Market Mutual Funds and Financial Stability." Remarks at the Federal Reserve Bank of Atlanta's 2012 Financial Markets Conference (April 11). www.bos.frb.org/news/speeches/rosengren/2012/041112/ 041112.pdf.

2013. Federal Reserve Bank of Boston comment letter regarding Financial Stability Oversight Council, "Proposed Recommendations Regarding Money Market Mutual Fund Reform" (February 12). www.regulations.gov/\#!document Detail;D=FSOC-2012-0003-0100.

Schapiro, Mary. 2010. "Statement on Money Market Funds before the Open Commission Meeting." Washington: Securities and Exchange Commission (January 27). www.sec.gov/news/speech/2010/spch012710mls-mmf.htm.

2011. "Remarks at SIFMA's 2011 Annual Meeting." Washington: Securities and Exchange Commission (November 7). www.sec.gov/news/speech/2011/ spch110711mls.htm.

- 2012. "Testimony on 'Perspectives on Money Market Mutual Fund Reforms' before U.S. Senate Committee on Banking, Housing, and Urban Affairs.” Washington (June 21). www.banking.senate.gov/public/index.cfm?FuseAction=Files. View\&FileStore_id=66f4ddb5-4823-4341-bad9-8f99cdf5fe9a.

Scharfstein, David S. 2012. "Testimony on 'Perspectives on Money Market Mutual Fund Reforms' before U.S. Senate Committee on Banking, Housing, and Urban Affairs." Washington (June 21). www.banking.senate.gov/public/ index.cfm?FuseAction=Files.View\&FileStore_id=ca1f8420-b2de-46dd-aee19a22d47b198c.

Sellon, Gordon H., Jr. 2003. "Monetary Policy and the Zero Bound: Policy Options When Short-Term Rates Reach Zero.” Federal Reserve Bank of Kansas City, Economic Review, 4th Quarter: 5-43.

Squam Lake Group. 2011. "Reforming Money Market Funds," Comment letter to the Securities and Exchange Commission regarding File No. 4-619, Release No. IC-29497, President's Working Group Report on Money Market Fund Reform (January 14). www.sec.gov/comments/4-619/4619-57.pdf.

Stevens, Paul Schott. 2011. Investment Company Institute comment letter to the Securities and Exchange Commission regarding President's Working Group Report on Money Market Fund Reform Options, File No. 4-619 (January 10). www.sec.gov/comments/4-619/4619-49.pdf.

U.S. Department of the Treasury. 2008. "Guarantee Agreement (Stable Value Single Fund)." Washington (September). www.treasury.gov/about/organizationalstructure/offices/Domestic-Finance/Documents/Guarantee_Agreement_StableValue_Single-Fund.pdf. 
U.S. Securities and Exchange Commission (SEC). 1999. "In the Matter of Craig S. Vanucci and Brian K. Andrew, Respondents: Order Instituting Public Administrative and Cease-and-Desist Proceedings." Administrative Proceeding File no. 3-9804. Washington (January 11). www.sec.gov/litigation/admin/33-7625.txt.

. 2005. "Final Rule: Mutual Fund Redemption Fees." File no. S7-11-04. Washington (March 11). www.sec.gov/rules/final/ic-26782.pdf.

. 2009. "Money Market Fund Reform: Proposed Rule." Release no. IC2880730. Washington (June 30). www.sec.gov/rules/proposed/2009/ic-28807. pdf.

2010. "Money Market Fund Reform: Final Rule." Release no. IC-29132. Washington (February 23). www.sec.gov/rules/final/2010/ic-29132.pdf.

. 2012. "Response to Questions Posed by Commissioners Aguilar, Paredes, and Gallagher," Washington (November 30). www.sec.gov/news/studies/2012/ money-market-funds-memo-2012.pdf.

. 2013. "Money Market Fund Reform; Amendments to Form PF." Release no. 33-9408. Washington (June 5). www.sec.gov/rules/proposed/2013/339408.pdf.

Volcker, Paul A. 2011. Comment letter to the Securities and Exchange Commission regarding File no. 4-619, Release no. IC-29497, President's Working Group Report on Money Market Fund Reform. Washington (February 11). www.sec. gov/comments/4-619/4619-79.pdf.

Witmer, Jonathan. 2012. "Does the Buck Stop Here? A Comparison of Withdrawals from Money Market Mutual Funds with Floating and Constant Share Prices." Bank of Canada Working Paper no. 2012-25. Ottawa (August). www.bank ofcanada.ca/wp-content/uploads/2012/08/wp2012-25.pdf. 


\section{Comments and Discussion}

\section{COMMENT BY}

MARTIN NEIL BAILY Money market funds (MMFs) currently play an important role in providing liquidity to financial intermediaries. At the end of 2012, these funds accounted for over one-fifth of all U.S. mutual fund assets, with $\$ 2.7$ trillion in assets under management. MMFs typically provide a higher yield than bank deposits, and before the recent financial crisis they were widely thought to be as safe as insured deposits, at least by retail investors, although their value was not in fact guaranteed by the government. As the crisis unfolded, wholesale investors began to doubt the stability of the funds and started to withdraw their shares. As Patrick McCabe and his coauthors point out in this paper, under the current rules governing MMFs, investors who are quick to redeem from a troubled MMF are able to protect both their liquidity and their principal, shifting the risks onto less savvy investors. This problem, inherent in the incentive structure of these funds, provides the context for the authors' proposed reform of MMFs.

The first MMF established was the Reserve Fund, which opened in 1971. From there the number of MMFs grew quickly, as they offered a way to avoid interest rate regulation on bank deposits (Regulation Q) and so reap higher returns. This is an important point, indicating that MMFs are a reflection of regulatory arbitrage, and since Regulation $\mathrm{Q}$ has now disappeared, the rationale for the continued existence of MMFs has come into question.

MMFs are regulated under the Investment Company Act of 1940 and under rule 2a-7 of the Securities and Exchange Commission (SEC), adopted in 1983, which allows MMFs to use a variety of procedures to maintain a stable net asset value (NAV) of $\$ 1$ per share. In only a few cases has an MMF's NAV dropped below this $\$ 1$ level ("broken the buck"): the authors report only two instances since 1983 . Yet there have been other cases where 
runs on MMFs resulted in portfolio losses, and in some of these the MMF would have broken the buck but for the support of its sponsoring financial institution. The authors note that since the birth of the MMF industry in the 1970s, sponsors have intervened to support an MMF in over 300 instances.

The vulnerability of MMFs to runs results in part from the fact that they generally hold similar portfolios. The restrictions they face-MMFs can hold only assets with the highest short-term ratings - coupled with their need to maintain a stable NAV, severely limit the diversification available to MMF portfolios. The authors point out that as of September 2012, 50 private issuers accounted for 91 percent of all MMF investments in private entities, and that of these 50, all but 4 were financial firms. Because the portfolios of different MMFs have a significant degree of overlap, trouble at one MMF very often has direct implications for others. The authors identify this as a "contagion risk among MMFs," whereby a surge in redemptions from one or more troubled MMFs can depress asset prices and put other MMFs with overlapping portfolios at risk. This gives investors an incentive to redeem preemptively from those MMFs as well.

These concerns became acute during the financial crisis, especially in 2008. In the weeks following the collapse of Lehman Brothers in September 2008, prime MMFs experienced an outflow of $\$ 400$ billion. During 2008 the Reserve Primary Fund lost 1.6 percent of its value. Almost all of this run behavior was on the part of institutional investors, whose holdings account for over 65 percent of all MMF shares. Retail investors, in contrast, displayed a great deal of inertia, in that they were significantly less likely to run from their MMFs.

In September and October 2008, more than two dozen MMFs received contributions from their sponsors in order to avoid breaking the buck. On September 19, 2008, the U.S. Treasury extended a guarantee to MMF investors that they could withdraw their funds without breaking the buck; that guarantee stayed in place until September 18, 2009. However, the Economic Stabilization Act of 2008 outlawed similar guarantees in the future. Thus, without a change in the law, the Treasury will not be able to guarantee MMFs in any future crisis.

I noted earlier that retail shareholders tended not to run from MMFs in the crisis, but that statement has to be qualified because of the Treasury guarantee. Retail shareholders did not run immediately in the crisis, but they might have run eventually without the guarantee. In 2010, in response to what had happened in the crisis, the SEC tightened its risk requirements for MMFs, mandating that they hold at least 10 percent of their assets in highly liquid assets, such as privately issued securities maturing within 
a day and Treasury securities, and at least 30 percent in assets maturing within a week.

At prevailing prices, investor demand for risk-free, liquid assets is strong. The government provides backing for a large share of these assets through the insurance of bank deposits by the Federal Deposit Insurance Corporation (up to a limit) and adds directly to the supply by issuing large volumes of short-term Treasury securities. Private markets look for additional ways to supplement the supply. For example, investors can circumvent the regulatory limit on insured bank deposits by spreading their assets across a number of banks. MMFs created demand deposits that technically carried some risk but were assumed by many investors to be risk free. In the crisis the Treasury felt obliged to validate that misperception, and so regulating MMFs must be part of a broader decision about the extent to which government, and hence taxpayers, should be on the hook to support risky assets. The Dodd-Frank legislation was clear in wanting to limit taxpayer liability and to avoid having the federal government dragged into providing such support in another crisis.

One of the things I liked about this paper is that it identifies a market failure in MMFs and devises a policy that is geared directly to addressing that failure. The authors argue that the current set-up of MMFs results in an externality, by allowing savvy investors to withdraw at the first signs of trouble and retain the full value of their principal, in the process passing the losses on to the investors who stay in the MMF. This encourages investors to run at the first hint of trouble, and the potential for such behavior compounds the riskiness of an MMF even if its underlying assets are in fact sound. Any institution that issues demand deposits of fixed value is prone to a run, because it is costless for investors to withdraw their money and hold it in cash or deposit it in an alternative liquid asset. Market failures in finance are often tied to incomplete or asymmetric information, and the authors make such a connection. The more savvy (and presumably richer) investors know more about the quality of a fund's portfolio and are able to pass the losses on to the smaller investors who are less informed.

Yet one can take a different perspective on MMFs and question the severity or even the existence of the market failure. It is important that investors monitor the health of the MMFs in which they place their assets, and take action if the fund managers fail to act in a manner consistent with the risk goals of the fund. In a climate of very low interest rates, fund managers have a tendency to "reach for yield," making risky investments in order to generate an adequate return or to attract investors by offering higher yields than competing funds. Savvy investors who withdraw assets 
from a fund are giving a signal to the market. Their exit serves as a counterbalance to the inertia of retail investors who pay no attention to the safety of the fund. In this view information is something investors can choose to acquire and use. This argument only goes so far, however, because large corporate investors will have much easier access to information and are better able to understand risks than small retail investors.

POLICY RESPONSES A variety of policy responses have been proposed to diminish the systemic risk introduced by MMFs. The first of these would abolish the fixed NAV. A floating NAV would communicate information to current and potential investors about the risks in an MMF's portfolio; all investors, wholesale and retail, would then be regularly informed about the value of the fund and the nature of its investments. Additionally, it is argued that a floating NAV would discourage risky investments on the part of MMF managers, as these risks would quickly be communicated to potential and current investors, to a much greater degree than is the case currently with the $\$ 1$ per share peg. Another benefit of this approach is that it would, at the margin, discourage preemptive redemptions by risk-averse investors, as any signal of trouble within the MMF would entail a decrease in the NAV, reducing the amount of their principal they recouped. Under current practice, in contrast, redeeming investors always get the same return of $\$ 1$. Finally, proponents of this view contend that the floating NAV is simpler than a peg, as the latter involves instruments used in rounding the NAV, which introduce complexities and costs.

One argument against this solution is that if very large investors were to suddenly withdraw their funds, it would be difficult for the fund to come up with the cash, even with a lower NAV. Robert Pozen, a long-time industry practitioner, has pointed out to me, however, that very large withdrawals can be dealt with by giving the redeeming investors a pro rata share of the fund's assets in kind, to dispose of as they wish.

Another argument against the floating NAV, offered by Samuel Hanson, David Scharfstein, and Adi Sunderam (2013), is that it may not prevent runs from becoming a systemic problem. With a floating NAV, they claim, investors will pull out even more quickly to avoid a price decline. One variant of the floating-NAV approach is to separate wholesale and retail funds. Since retail investors are "stickier" and less prone to runs, retail funds may not need the same rules as for wholesale funds.

The authors of this paper propose a second policy solution to MMF regulation, which they call the minimum balance at risk (MBR). The basic idea is that a small proportion of an investor's total holdings in an MMF 
would be subject to a delay (they propose 30 days) if the investor attempts to redeem during a potential run. A second component of the proposal is that of subordination, whereby in the event of a run, the MBRs of those investors who have chosen to redeem early would be the first assets used to absorb whatever losses the MMF incurs. Rather than spreading the losses evenly across MBRs, the proposal would have the MMF manager preferentially protect the MBRs of those investors who decide to stay put. The virtue of this proposal is that it speaks directly to the externality whereby the first investors to withdraw pass the costs on to the less savvy investors left behind. Instead, under the MBR proposal, the investors who try to get out first would be forced to bear more of the costs. Thus, the proposed solution acts directly to restrain runs on MMFs by penalizing those investors who run.

The authors do a nice job of laying out the specifics of their proposal, and they show that if an MMF also maintains a small capital buffer in place ( 0.5 percent), the MBR could be set at a level of about 3 to 5 percent of shares. They examine the impact of different shocks and the nature of the protection provided by MBRs of different sizes and structures.

A concern about the MBR proposal is that it works against one of the major appeals of MMFs, namely, that they provide an investment vehicle for highly liquid assets that can respond rapidly to changing market opportunities. Instituting a 30-day delay on a portion of redemptions may adversely impact investors' business decisions. It may also dampen the appeal of the MMFs themselves. Even if the MBR were applied only where there is a risk of a run, its imposition may discourage the use of MMFs out of concerns about the possible implementation of the MBR plan. At the retail level, investors concerned about paying taxes on time or being surprised by medical expenses will be reluctant to wait 30 days to redeem their funds. Aware of this problem, the authors discuss possible exemptions for smaller retail investments.

The third possible approach to MMF regulation is the capital buffer proposal made by Hanson and coauthors, which has also been endorsed by the Squam Lake Group, of which I am a member. The idea is straightforward. MMFs would be required to hold loss-absorbing capital equal to some percentage of their assets, so that if the value of the assets declines, the capital can be used to preserve the fixed NAV and allow investors to withdraw their funds at par. The presence of a capital buffer, it is argued, would discourage investors from running and thus avoid or at least mitigate the systemic risk problem. 
One problem with a capital buffer is determining how large the buffer should be in practice. A buffer that is too small may be quickly overwhelmed, putting the fund back in a floating-NAV situation. But if the buffer is too large, it will reduce the returns that the MMF is able to achieve, possibly destroying its economic viability. A second problem with a capital buffer is that it may bolster the all-too-common but mistaken belief that MMF investments are without risk.

WEIGHING THE ALTERNATIVES The problem of MMF regulation has no easy answer-witness the slowness of the SEC to implement new rules. In fairness, the SEC did act promptly to require MMFs to keep a set proportion of their assets liquid, a step that made the funds more robust to sudden withdrawals.

Some of the participants in the Brookings Panel discussion of this paper argued that MMFs are really an anomaly that grew out of Regulation Q and have now outlived their usefulness. I am quite sympathetic to that view, provided that any transition away from MMFs is made smoothly. At present, MMFs provide short-term funding to other financial institutions, but if they were to lose their competitive advantage, the wholesale and retail shares they now hold would flow back into bank accounts or into other financial institutions, where they would be available to be recycled.

If instead MMFs are given a chance to survive and compete, my preferred regulatory proposal is that they eliminate the fixed NAV. Wholesale investors understand fluctuations in asset values and can decide whether or not they wish to continue keeping funds in an instrument with a variable price. Many retail investors in MMFs also hold stock and bond mutual funds and are quite aware of the ups and downs of the market. Investors in floating-NAV funds should be warned that their principal is at risk, and if they do not like small price variations, they should hold their money in insured bank accounts instead. It is important to have clarity about the extent of government insurance of demand deposits.

There is not a generally accepted theory of what causes financial market panics, but it seems that most runs occur when some party tries to maintain a fixed price for some asset in the presence of fluctuating demand and supply. As soon as the fixed price comes into jeopardy, everyone rushes for the exit. For example, in currency crises a country tries to maintain a fixed exchange rate but eventually is forced to devalue. Having a capital buffer for MMFs seems rather similar to having foreign exchange reserves, with the same danger that in very adverse circumstances, investors will try to run before the reserves are used up. The MBR proposal is actually rather like the capital buffer, except that the buffer is provided by setting aside a 
percentage of each shareholder account. Since I am not sure what drives unstable financial dynamics, some humility is in order, but I do not buy the argument that a variable NAV will make investors more likely to run in a new crisis. And as noted earlier, a variable NAV communicates the message beforehand that there is principal risk.

Since the Panel meeting, the SEC has issued proposed new rules, described in a 700-page document with a request for comments. The SEC proposal suggests that MMFs could choose to have a floating NAV, but it offers an alternative option whereby they could keep a fixed NAV as long as their liquidity ratio (the fraction of the fund's assets with maturity of one week or less) remains above 15 percent. Once the ratio falls below that point, the fund's board could decide either to impose a 2 percent fee on withdrawals ( $\$ 98$ back for every $\$ 100$ invested) or to "gate" (put a hold on) redemptions for a period of time. Although not the same as the MBR proposal, the SEC has thus opted for a restriction on withdrawals as the leading alternative to a floating NAV.

\section{REFERENCE FOR THE BAILY COMMENT}

Hanson, Samuel, David Scharfstein, and Adi Sunderam. 2013. "An Evaluation of Money Market Fund Reform Proposals." Working paper. Harvard Business School.

\section{COMMENT BY}

SAMUEL G. HANSON Many academics, policymakers, and market participants have recently been pushing for a significant overhaul of money market fund (MMF) regulations. Others oppose any significant changes in these regulations. Why has this historically sleepy corner of the mutual fund sector become a frontline battle in the postcrisis debate about financial regulation? And what can this debate tell us about the theory and practice of financial regulation and its future prospects for success?

In this superb and timely paper, Patrick McCabe, Marco Cipriani, Michael Holscher, and Antoine Martin put forth a novel proposal for MMF reform, which they call the minimum balance at risk (MBR). I begin this discussion by providing some further background on MMFs and explain why a growing number of observers believe that MMFs pose a significant threat to financial stability. I contrast various approaches to financial regulation and argue that the current debate over MMF regulation is best understood through the lens of systemic financial regulation: the goal of 
these proposals is to better safeguard the stability of the financial system. Drawing heavily on my own recent paper with David Scharfstein and Adi Sunderam, I then lay out what I see as the main goals of MMF reform. Finally, I evaluate three prominent reform proposals-floating net asset values (NAVs), the MBR proposal, and subordinated capital buffers-in light of these goals. I note that the MBR is a form of subordinated capital, so the second and third proposals are close cousins. I argue that these two proposals are far more likely to achieve the goals of MMF reform than floating the NAV.

BACKGROUND ON MMFS A money market fund is a type of mutual fund that is required by law to invest in short-term, low-risk securities. MMFs pay dividends that reflect the level of short-term interest rates. MMFs come in institutional and retail varieties. Institutional MMFs are highminimum-investment, low-expense funds marketed to large firms and institutional investors. Retail MMFs are low-minimum-investment, higherexpense funds marketed to households.

Like other mutual funds, MMFs are not insured by the Federal Deposit Insurance Corporation (FDIC) and are regulated by the Securities and Exchange Commission under the Investment Company Act of 1940. However, because MMFs have very low risk compared with other mutual funds, they are exempt under rule 2a-7 of the act from certain regulations that apply to mutual funds more broadly. Specifically, an MMF is not required to mark its assets to market as long as its NAV per share is greater than $\$ 0.995$. Instead MMFs, like banks, are allowed to use amortized-cost accounting. However, MMFs are subject to a variety of bank-like regulations that explicitly restrict their asset risk, again setting them apart from other mutual funds.

In November 2012 the Financial Stability Oversight Council (FSOC) solicited public comment on a range of structural reform proposals for MMFs. ${ }^{1}$ The principal concern cited by the FSOC is that a wide-scale run on MMFs could result in a systemwide run on large financial firms. Such a run would, in turn, disrupt credit markets and the payments system, with severe adverse consequences for the real economy. This is the "systemic risk posed by MMFs" that motivates the proposal of McCabe and coauthors.

The FSOC asked for comments on three reform proposals for MMFs: the first would require MMFs to "float" their NAVs; the second would

1. The FSOC was created by the Dodd-Frank Wall Street Reform and Consumer Protection Act of 2010, which grants the FSOC broad authority to monitor and respond to emerging threats to financial stability. 
require MMFs to maintain a 1 percent subordinated capital buffer and adopt a 3 percent MBR; the third would require MMFs to maintain a 3 percent subordinated capital buffer but no MBR. The second alternative is a variant of the proposal described by McCabe and coauthors and draws heavily on their work.

WHAT DO MMFS DO? Like the authors in this paper, I focus here on prime MMFs, which are thought to pose the greatest systemic risk. Prime MMFs invest in short-term debt instruments issued by private borrowers, mainly large, global banks; only 3 percent of prime MMF assets are in paper issued by nonfinancial firms. ${ }^{2}$ Thus, the core function of prime MMFs is to collect savings from households and firms to provide short-term financing to financial institutions (Hanson, Scharfstein, and Sunderam 2013). In other words, prime MMFs function like "correspondent banks" that take deposits and invest those funds in the deposits of other banks.

Prime MMFs create a number of bank-like benefits. On the liability side, they provide savers with money-like, demandable claims - that is, claims with a highly stable nominal value that are redeemable on demand-and offer a variety of transactional services. In addition, MMF shares pay an interest rate that closely tracks movements in short-term market rates such as the federal funds rate, making them attractive relative to the savings products offered by commercial banks (such as savings and money market deposit accounts), which typically pay below-market rates. On the asset side, prime MMFs function as delegated monitors and asset managers, providing savers with access to a diversified portfolio of the short-term liabilities of many large banks. Access to a more diversified portfolio is useful to savers, and delegation may reduce duplicative monitoring in the spirit of Douglas Diamond (1984).

However, MMFs also pose a set of bank-like risks to the stability of the financial system. Since MMF shares are subject to redemption on demand each day, the existence of MMFs arguably raises the risk of a systemwide run due to the greater systemwide maturity transformation they provide. For instance, imagine a world in which large banks financed themselves by issuing 10-day certificates of deposit (CDs). In such a world, the banking system would need to roll over 10 percent of its funding every night. Now

2. MMFs are classified as prime, government, or tax-exempt. According to the Investment Company Institute, MMFs managed a total of \$2.60 trillion in assets as of November 2012. Most of these assets ( $\$ 1.45$ trillion) were in prime MMFs. The remainder were in government MMFs ( $\$ 0.87$ trillion), which hold Treasury bills and other short-term U.S. government and agency paper, and in tax-exempt MMFs (\$0.27 trillion), which hold short-term paper issued by states and municipalities. 
imagine that an MMF sector is inserted between savers and banks. Specifically, suppose that savers invest all of their funds in MMFs, which then buy the banks' 10-day CDs. Because the MMF shares are redeemable on a daily basis, the financial system would now need to roll over 100 percent of its funding each night, so it is reasonable to conclude that the risk of a systemwide run has increased.

Delegated monitoring also opens the door to agency problems and raises the classic question of "who monitors the monitor?" Indeed, a number of recent studies suggest that MMFs have strong private incentives to take on excessive portfolio risk ex ante (Kacperzyck and Schnabl forthcoming, Chernenko and Sunderam 2013). An increase in an individual fund's risk will increase that fund's yield. This increase in yield is likely to result in significant additional inflows from institutional investors, who seek out riskier MMFs with higher yields because they believe they can redeem their shares before bearing any losses. But when investors protect themselves in this way, they exacerbate stresses on MMFs ex post, potentially triggering more widespread financial instability. This yieldseeking behavior also means that MMFs take risk at the worst times from a systemic perspective: the imposition of market discipline occurs in a disorderly fashion late in a crisis, rather than in an orderly fashion in the early stages of a crisis.

FINANCIAL REGULATORY APPROACHES Before I discuss the specific goals of MMF reform, it is worth contrasting several different regulatory approaches: traditional securities regulation, traditional bank regulation, and systemic financial regulation. This contrast is relevant since proponents of overhauling MMF regulations typically adopt the systemic perspective, whereas opponents of significant MMF reform typically advocate more traditional regulatory approaches.

The primary goals of traditional securities regulation-for example, as embodied in the Securities Act of 1933, the Securities Exchange Act of 1934, and the Investment Company Act of 1940 - are to ensure that all investors are properly informed about investment products and can transact at fair market prices. More specifically, the goal of traditional securities regulation is to increase transparency, reduce asymmetric information, and protect unsophisticated retail investors.

The goal of traditional bank regulation is to ensure that each individual bank is sufficiently "safe and sound"-for example, that it has enough equity capital — to ensure that FDIC losses and taxpayer bailouts are highly unlikely. For this reason traditional bank regulation is sometimes described as "microprudential" in nature. The market imperfection motivating micro- 
prudential bank regulation stems from moral hazard. Given the existence of mispriced deposit insurance, banks have incentives to take excessive risks to maximize the expected value of taxpayer support. Thus, traditional bank regulation is seen as a necessary counterweight to this moral hazard. Since this view is tied to the existence of deposit insurance, traditional bank regulation is institutional rather than systemic in nature-for example, from this perspective there is no need to regulate a bank that has no recourse to the taxpayer safety net.

Following Hanson, Anil Kashyap, and Jeremy Stein (2011), I take the goal of systemic financial regulation to be that of mitigating the excessive contractions in credit or disruptions of payments that may arise when the financial system is hit with an aggregate shock. Since the goal is to ensure that the financial system as a whole is safe and sound, this is often described as "macroprudential" regulation. In contrast to traditional securities and bank regulation, systemic regulation is decidedly general equilibrium in conception. The idea is that because the financial system is subject to fire-sale and credit-crunch externalities, the amount of leverage and maturity mismatch that is privately optimal for individual financial firms may not be socially optimal, since it makes the system as a whole overly vulnerable to costly financial crises. Since these externalities can arise even in the absence of FDIC-induced moral hazard, systemic regulation is functional as opposed to institutional. Indeed, the systemic regulator worries about credit disruptions from regulated depository institutions, nonbank financial institutions, and markets alike.

GOALS OF MMF REFORM For proponents of systemic financial regulation, prime MMFs appear to be a prime example of regulatory arbitrage. MMFs perform the core economic activities that define banking-they finance illiquid assets with demandable liabilities and undertake liquidity transformation-and pose risks to financial stability similar to those posed by banks. However, unlike banks, MMFs are not subject to subordinated capital requirements and only recently have become subject to bank-like liquidity requirements, two regulatory tools often advocated by proponents of systemic regulation.

Thus, in Hanson and others (2013), we look at MMF regulation through the lens of the systemic approach to financial regulation. We argue that the primary objectives for MMF reform should be threefold. First, regulation should reduce MMFs' incentives to chase yield and take excessive risk ex ante. Second, regulation should reduce the likelihood of a widespread and systemically disruptive run on MMFs. And third, regulation should attempt to preserve the monetary services that MMFs provide to savers. Otherwise 
one worries that savings will flow toward unregulated, MMF-like products that would continue to pose the same risks to financial stability.

EVALUATION OF REFORM PROPOSALS I nOw discuss the three main alternatives for structural MMF reform that have been put forward by the FSOC: floating the NAV, subordinated capital buffers, and the MBR provision.

Floating the NAV The first proposal is to require MMFs to float their $\mathrm{NAV}$, that is, to report their true NAV and allow investors to transact at it every day, just as all other mutual funds do. This proposal has natural appeal for adherents of traditional securities regulation, since it increases the transparency of MMFs. It may also address the worry that a fixed $\$ 1.00$ NAV per share places retail investors at a disadvantage because institutions are able to pull their money out more quickly when trouble arises.

However, proponents of floating the NAV also cite two potential systemic benefits. First, moving to a floating NAV may lower the probability of "strategic" runs on MMFs. Currently, if the true NAV falls, investors who redeem early receive $\$ 1.00$ per share, while those who redeem late receive less. This cliff effect creates a strategic motive to run. Second, moving to a floating NAV might lower the probability of "panicked" runs, because it would remove the regulatory imprimatur of safety that MMFs enjoy and force skittish, risk-averse investors to recognize that MMFs are not completely safe.

In Hanson and others (2013) we argue that these systemic benefits are likely overstated. First, since most prime MMF assets tend to be quite illiquid-secondary markets for short-term private paper are extremely thin - the strategic incentive for MMF investors to run at the first sign of danger is likely to remain. Specifically, the incentive to run stems from the combination of demandable liabilities and illiquid assets, as in Diamond and Philip Dybvig (1983), not simply from the cliff effect due to a fixed \$1.00 NAV. Investors who redeem early get paid in full but consume the fund's more liquid assets. By contrast, investors who redeem late will receive the depressed, fire-sale value of the fund's more illiquid paper. Indeed, the recent crisis also saw widespread runs on MMF-like products with variable NAVs, including ultra-short bond funds in the United States and variable-NAV MMFs in Europe.

Second, floating-NAV MMFs would continue to attract a highly skittish, risk-averse investor base. They would still be subject to strong risk-limiting provisions under rule 2a-7 and thus would continue to benefit from a strong regulatory imprimatur of safety. Furthermore, since the NAV would fluctuate little, if at all, in normal times, highly risk averse investors would still be drawn to the product, setting the stage for runs at the first sign of danger. 
Subordinated capital buffers The idea of a junior capital buffer is quite simple. A capital buffer divides the risks and rewards of MMF assets between subordinated capital, which bears the first losses, and ordinary, senior MMF shares. In return for the protection provided by a subordinated capital buffer, the latter would earn a slightly lower yield in normal times.

In Hanson and others (2013) we argue that subordinated capital buffers are the preferred regulatory solution from the standpoint of reducing systemic risk, for several reasons. First, junior capital reduces the probability of systemwide runs. Senior MMF shares will be protected by the capital buffer, so MMFs would have to suffer larger losses than under current rules before ordinary MMF investors are endangered. Second, because subordinated capital providers bear the first losses, they will have an explicit incentive to discipline ex ante risk taking. Indeed, Marcin Kacperzyck and Philipp Schnabl (forthcoming) show that fund sponsors, who implicitly have capital at stake, rein in the risk taking of their MMFs. Finally, subordinated capital preserves - and potentially enhances - the monetary benefits enjoyed by ordinary MMF shareholders and would be unlikely to trigger a migration to less regulated savings products.

Hanson and others (2013) perform a calibration based on Oldrich Vasicek's (2002) model of credit portfolio losses. For a well-diversified portfolio of MMF assets, our estimates suggest that a 4 percent subordinated capital buffer would reduce the probability that senior shares suffer losses to 0.1 percent, the tolerance level used in the Basel II bank capital regulations. In return for this protection, we estimate that senior shares would earn just 0.05 percent less in normal times.

Minimum balance at risk Under the minimum balance at risk proposal of McCabe and coauthors, some fraction (say, 3 or 5 percent) of each investor's recent balances would be available for redemption only with a delay of 30 days. This would ensure that sophisticated investors cannot chase yield and then run at the first sign of danger, sticking less sophisticated investors with all the losses. Furthermore, the "strong MBR" proposal advocated by these authors adds a conditional subordination feature whereby the MBRs of redeeming investors become subordinated relative to those of nonredeemers and bear the first losses if the MMF breaks the buck. As the authors argue, this strong MBR provision provides an explicit disincentive for MMF investors to withdraw when concerns about moderate fund losses arise.

Thus, the proposed MBR is a form of subordinated capital. The main differences between an actual capital buffer and the MBR have to do with who provides the capital and when they provide it. With an MBR, risk-averse 
MMF investors are forced to provide junior capital ex post. With a capital buffer, other, more risk tolerant investors or the fund sponsor provide this junior capital ex ante.

There are costs and benefits of each approach. The MBR may be more effective at discouraging excessive risk taking, because the MMF investors themselves are forced to bear the costs of chasing yield ex ante. With respect to reducing the tendency for investors to run ex post, note that the MBR assigns losses to skittish, risk-averse investors in a complex fashion, whereas a capital buffer assigns losses to more risk tolerant investors in a simple fashion. If one adopts a rational, strategic view of runs, the MBR may be more effective at discouraging them. However, if one adopts a more behavioral, panic-based view of runs, one might worry that the MBR would be less effective. Finally, the MBR may partially diminish the value of the monetary services provided by MMFs. As a result, one may worry that a large MBR requirement might lead savers to substitute away from MMFs and toward other unregulated products, which may also pose threats to financial stability.

Overall, a subordinated capital buffer and an MBR are quite similar, and either could largely achieve the goals of MMF reform. Furthermore, as the authors note, these approaches may be complementary, so that a hybrid of buffer and MBR solutions may be most effective.

CONCLUSION In the aftermath of the crisis, the broad question is where to draw the line between investment products that can be left largely unregulated, such as hedge funds, and core financial and payments services that require stronger regulation. The debate on MMF reform reflects this broader question. Floating-NAV proposals hope to move MMFs firmly into the investment category, a realm where policymakers are typically happy to stop at the objectives of traditional securities regulation. Proposals for capital buffers and MBRs would bring MMFs further under the regulatory umbrella in the name of systemic risk regulation. I have argued that the combination of demandable liabilities and illiquid assets that defines MMFs means that a systemic or macroprudential approach is essential and, thus, that the latter approach is likely to be most effective.

\section{REFERENCES FOR THE HANSON COMMENT}

Chernenko, Sergey, and Adi Sunderam. 2013. "Frictions in Shadow Banking: Evidence from the Lending Behavior of Money Market Funds." Working paper. Harvard Business School.

Diamond, Douglas. 1984. "Financial Intermediation and Delegated Monitoring." Review of Economic Studies 51, no. 3: 393-414. 
Diamond, Douglas, and Philip Dybvig. 1983. "Bank Runs, Deposit Insurance, and Liquidity." Journal of Political Economy 91, no. 3: 401-19.

Hanson, Samuel, Anil Kashyap, and Jeremy Stein. 2011. “A Macroprudential Approach to Financial Regulation.” Journal of Economic Perspectives 25, no. 1: 3-28.

Hanson, Samuel, David Scharfstein, and Adi Sunderam. 2013. "An Evaluation of Money Market Fund Reform Proposals." Working paper. Harvard Business School.

Kacperczyk, Marcin, and Philipp Schnabl. Forthcoming. "How Safe are Money Market Funds?" Quarterly Journal of Economics.

Vasicek, Oldrich. 2002. "Loan Portfolio Value.” Risk 15: 160-62.

GENERAL DISCUSSION Robert Pozen argued that those money market funds that invest only in government-issued securities should be exempt from any minimum balance at risk, because these funds carry very little risk and hence are unlikely to experience a run. Indeed, during the 2008 crisis, many of these funds received inflows from the prime money market funds, which invest primarily in nongovernment securities.

Pozen, who noted by way of disclosure that he had formerly been president of FMR Company, the investment adviser to the Fidelity funds, also pointed out that prime money funds have average maturities of only about 60 days and are required to hold at least 97 percent of their assets in the highest-rated short-term paper, and the remainder in the next-highest category. Thus, any notion that these funds might invest in highly risky securities was unfounded. Moreover, these funds are now required to hold 30 percent of assets in so-called liquidity buckets, which are redeemable in either one or seven days, making them highly liquid. Finally, among those money market funds that cater to large institutional investors, some have offered redemptions in kind at times when liquidity was strained: institutions seeking to make large withdrawals were instead given a pro rata share of the securities in the fund's portfolio. That option, Pozen suggested, could be used more widely. All these arguments weakened the case, in his view, for further regulation of money market funds.

Pozen nevertheless recognized that a credible case could be made for further regulation of institutional money market funds. The institutions that park money in these funds often hold very large positions, and they monitor the markets closely and trade actively, so that a run becomes a real danger. It was no coincidence, Pozen observed, that the only two money funds to date that have broken the buck were both institutional funds. 
By contrast, an MBR - and indeed any of the regulatory proposals currently on the table-would essentially put the retail money market funds out of business, in Pozen's estimation. The small investors that currently use such funds would simply shift their money to banks, which do not face such restrictions. Further regulation of these funds seemed to Pozen unnecessary in any case, because most retail money fund investors did not run even during the 2008 crisis, and since then the 30 percent liquidity bucket requirement has made those funds even safer.

On the asset side, Pozen noted that money market funds, with some $\$ 3$ trillion in assets, are today the most important short-term lenders to many large companies, banks, and municipalities. If further regulation led investors to abandon these funds, he asked, who would step up to do that lending in their stead? Banks probably would not, because they are more interested in longer-term lending where their specialization in maturity transformation produces greater profits. If banks did take up the slack, they would need to increase their equity capital, at a time when they are already struggling to raise capital. A likely scenario, Pozen thought, was that new types of hedge funds or private equity funds would emerge to meet the short-term needs of banks. These new lending vehicles would be largely unregulated and would likely trade more actively than the institutions that today finance the short-term market for money market instruments. The result, ironically, could be to increase the likelihood of a run in the short-term market.

Raquel Fernández was unclear about how the authors were able to calculate that runs would occur with lower probability with an MBR than without one. As she saw it, the situation was essentially characterized by multiple equilibria: if a sufficiently large fraction of investors decide to run, a run will occur. She did not see how an MBR would change that dynamic so that a probability of a run could be calculated.

Benjamin Friedman thought that more regulation of money market funds was called for, and his own preference would be to do away with the fixed share price and mandate a floating net asset value. More fundamentally, however, Friedman asked what difference it would make if the institutional money fund industry simply went out of business. As Samuel Hanson had pointed out in his discussion, prime institutional money funds today are mainly lending to banks, and in particular the broker-dealer operations of foreign banks: a recent paper by David Scharfstein showed that of the 50 largest borrowers from these funds, almost all were banks, and indeed most were non-U.S. banks; hardly any were nonfinancial businesses. Although there was nothing wrong with borrowing and lending 
taking place between consenting parties, domestic or foreign, Friedman saw no reason such lending should be a public policy priority. However, intermediation of such activity by money market funds in particular gave rise to a systemic risk that needed to be regulated, Friedman argued. It was thus worth asking whether the institutional money fund industry needed preserving in the first place.

Retail money market funds, on the other hand, do provide a worthwhile service to small investors, Friedman argued. But that, in his view, did not necessarily imply a need for further regulation of that part of the industry. Mutual fund families like Fidelity operate money market funds so that when investors decide to sell their shares in, say, the Fidelity Magellan Fund, and are not yet ready to buy shares of another Fidelity fund, the money stays with Fidelity. The fund families thus have an incentive to subsidize their money funds, as indeed they have proved willing to do, to assure investors of their safety.

Kristin Forbes wondered what evidence was available about the likely response of money market fund investors to the MBR proposal. Would they in fact shift their money to banks? or perhaps to foreign money market funds? If the latter, what impact would that have on total liquidity in the United States? She was also interested in knowing more about how the mutual fund industry itself rank-ordered the various reform proposals. Given their evident opposition to all of them-floating NAVs, increased capital requirements, MBRs - which did they see as the least of the various evils, and why?

George Perry, who like Pozen had been active in the mutual fund industry, also saw money market funds as providing a valuable service within the financial system and to retail investors in particular. When interest rates rose in the 1970s, bank deposit rates were prevented by Regulation Q from rising in tandem, effectively excluding small investors from reaping the higher returns. Money funds, he felt, should not be regulated out of existence just because they compete with banks. And with interest rates currently at almost zero, any additional cost due to increased regulation would erase the remaining margin and effectively wipe out the money fund industry.

Perry also questioned whether any of the proposed reforms would have their intended effect in a real crisis like that of 2008-09. Larger capital buffers could in principle help smooth out fluctuations of the magnitude that occur in normal times, thus allowing the one-dollar NAV to be maintained, but would not protect against an event like the Lehman Brothers bankruptcy. In Perry's view, a reform that worked only some of the time, but not when needed most, was unlikely to justify its additional cost. 
Richard Cooper seconded Friedman in questioning the paper's basic assumption that the money market fund industry was something worth preserving. He agreed with Perry that these funds had served an important purpose in the 1970s, but that purpose was one of regulatory arbitrage and presumably disappeared when the regulation did. Cooper also challenged Pozen's contention that banks are interested only in lending long. Historically, Cooper noted, an important function of banks was to provide trade credit, an inherently short-term activity; he saw no reason why banks today could not again profitably operate at the short end of the yield curve. Cooper acknowledged that the sheer volume of assets involved made it prudent to establish a period of transition, and he suggested a period of five or six years for the funds to either adapt, become banks themselves, or exit.

Justin Wolfers argued that the difficulty in judging among regulatory proposals for money market funds stemmed from the underlying presumption that demand exists for an asset of perfectly stable value, which implies a discontinuity in the utility function. It was unclear to Wolfers how that discontinuity arises, and thus unclear how to evaluate the welfare consequences of any given proposal. Approaching the issue in terms of Kahneman-Tversky-style risk aversion seemed unhelpful, because the players involved in the institutional segment of the market are more sophisticated than typical Kahneman-Tversky-type actors.

Laurence Ball added his voice to those questioning the need to preserve money market funds as an institution. In their absence, savers seeking maximum safety could use ordinary insured bank accounts, and short-term borrowers could take out lines of credit from the same bank. He pointed out that even if short-term lending is an unattractively low margin business today, it might become less so as savers and borrowers shift their activity from money funds to banks. Ultimately, he asked, if people are attracted to money funds because they are bank-like, what prevents banks from providing the same service?

Ricardo Reis agreed with Samuel Hanson that the key underlying problem raised by money market funds was the fire-sale problem: a fund experiencing large redemptions must sell off large amounts of assets, pushing their market price downward and thus lowering the firm's NAV. Anticipating this, investors redeem even more, even sooner, and the result is a rush toward the exits at the first hint of trouble. From that perspective, Reis thought, the MBR proposal made sense as far as it went, because in effect it turned what were one-day-callable deposits into 30-day-callable deposits. But the MBR would still perform liquidity transformation only over a 
longer time frame. Thus, Reis saw the proposal as vulnerable to the Lucas critique: with an MBR in place, funds will be led to invest in somewhat longer term assets: 60-day options, say, instead of 30-day options. A term mismatch will remain, and investors will still have an incentive to run when trouble looms. With the transition to the 60-day options, bank runs will simply take place over the longer period. Moreover, Reis observed, banks, too, are subject to the fire-sale problem, and this led him to wonder: If MBRs are a good idea for money market funds, why are they not also a good idea for banks?

Frederic Mishkin focused on the authors' point that an MBR actually creates a disincentive to redeem when the fund is facing difficulties. As he saw it, that implied that the MBR made funds even more illiquid than the authors claimed: not only was the amount subject to subordination5 percent in the authors' example-less liquid than before; rather, the entire amount invested was less liquid. If that was the case, it defeated the whole purpose of such funds.

Mishkin was agnostic as to whether money market funds had any distinct rationale in the post-Regulation Q era. Some innovations, he suggested, arise by historical accident, under stressful conditions that ultimately prove temporary, but once discovered are found to have lasting value. Money market funds could be such an innovation. That said, if present arrangements in the money fund market are seen as subsidizing risk taking in some way, his recommendation was to either remove the subsidy or tax it away, and then let the market determine whether the funds survive or become extinct. Unfortunately, Mishkin noted, the money market funds industry has devoted enormous resources to avoiding any kind of regulation, and so far it has largely succeeded. Hence, aside from the pure economics of the issue, there was also an issue of political economy to be addressed, which Forbes had touched on: are any of the current regulatory proposals both effective and sufficiently salable to the interests involved to have a chance of being enacted?

David Romer pointed out that nothing in the authors' proposal would prevent money fund investors from, in effect, buying insurance against becoming subject to an MBR, for example by creating derivatives that imposed on a third party the obligation to pay the MBR when it bound. Such an instrument would effectively convert the MBR into a capital requirement, with the third party providing the capital. Or, more precisely, it gave market participants the option of submitting to the MBR or paying in capital. That flexibility seemed to Romer a point in the proposal's favor. 
Romer also noted that the existence of money market funds was seen by some as an important constraint on monetary policy: in this view, one reason the Federal Reserve has refrained from lowering the federal funds rate all the way to zero is that doing so would wipe out any margin the money funds still earn, causing every one of them to break the buck. This kind of monetary forbearance, Romer argued, imposes a real social cost: a further 50 basis points of interest rate reduction in the current environment would do a lot of economic good. Was preserving the money fund industry worth it, or might some form of regulation be found that removed that barrier to further monetary ease?

Gerald Cohen lamented the widespread misconception among retail money fund investors that they were reaping a higher return than they could get at a bank, with no countervailing increase in risk. Although the danger of a run comes mainly from the institutional money fund investors, the misplaced confidence of retail investors that their money fund will never break the buck is potentially costly as well, because it may give rise to a disequilibrium.

Donald Kohn sought to reassure the money funds' defenders that the various reform proposals were not intended to drive the funds out of business, but only to internalize the externality they created. Kohn himself saw the need for such measures as all the greater, given that the Dodd-Frank legislation has set limits on potential government support for these funds in a future crisis. For example, the Federal Reserve now has to jump through many more regulatory hoops when it wishes to extend section 13(3) loans to nonbank institutions, and there is a much greater emphasis on security and collateral than before the act was passed. Now that Congress has decided that money funds will not be bailed out in the next crisis, Kohn saw it as imperative that the systemic risks they pose be minimized. He agreed that neither increased capital nor MBRs nor floating NAVs would suffice to prevent another major crisis, but such measures might at least alert the public to the fact that money funds have risks.

Liliana Rojas-Suárez cautioned the Panel against expecting too much from a single reform of one part of one side of the financial system's ledger. As she saw it, the core of any systemic banking crisis is on the asset side - not the liability side, which the MBR addressed. She doubted that a reform that focused only on one type of bank funding would do much to reduce systemic risk, and she worried that reform of the money fund industry undertaken in isolation would lead to regulatory arbitrage, causing assets to be channeled to other, unregulated or less regulated instruments and institutions, possibly in foreign financial havens. 
Steven Davis expanded on Reis's point that if MBRs would be good for the money market funds, they should be good for banks as well. $\mathrm{He}$ observed that many of the costs associated with a run are internal to the institution - broadly defined to include both shareholders and depositorsexperiencing the run. That implies that financial institutions themselves have strong incentives to prevent runs, especially when no public provider of deposit insurance or lender of last resort is present. This observation led Davis to wonder whether there was anything to learn from the pre-deposit insurance era in the United States. Did banks back then experiment with MBRs or MBR-like mechanisms? If not, why not?

Bradford DeLong, addressing Davis's question, said that the New York banks, at least, of that era dealt with crises by explicitly suspending payment on deposit accounts. They gave depositors the choice of taking their money out on the spot at 98 cents on the dollar, or forbearing while J. P. Morgan and the other captains of finance tried to resolve the crisis, and receiving 100 cents on the dollar if they succeeded. This kind of private ad hoc central banking worked reasonably well, as evidenced by the fact that the public did not abandon their use of banks in the crisis's aftermath. Jeffrey Miron added that the banks in these episodes often took these extreme steps in the face of explicit prohibition by state and other regulators, which under the circumstances either looked the other way or actively encouraged or even directed the banks to suspend payment. DeLong cited similar instructions from the British chancellor of the Exchequer to the governor of the Bank of England during the 19th century.

The discussion of past policy responses prompted Christopher Carroll to cast the net further. Many countries today, he observed, have welldeveloped financial systems today that did not have them in J. P. Morgan's day. Have any of these experimented with solutions to runs from which lessons could be drawn?

Responding to the discussion, Patrick McCabe suggested a general framework for thinking about money market funds. He observed that these funds at present claim to offer three benefits: principal stability, immediate and complete liquidity, and market-based yields that reflect holdings with some credit risk. That, he posited, was not a tenable combination, and because of the externalities it generated, something had to be given up. If one believes that by sacrificing one of these three features, the money fund industry becomes nonviable, that says something about whether it should have existed in the first place. He and his coauthors were persuaded, however, that a portfolio system of regulation could be devised where investors themselves could choose which of the three mutually 
incompatible features to give up, and the money fund industry could in principle survive. In the end the authors were agnostic as to whether the industry should survive, but they believed that it could survive without creating a permanent and costly distortion.

McCabe remarked further that the paper's intention was not to offer a global solution but only to describe the specific MBR proposal. That said, the authors believed that an MBR could usefully complement increased capital requirements. Large capital buffers might prove effective for a number of years only to be overrun in a major crisis, as Perry had noted; the MBR provided a disincentive to such a run. The two measures could thus work in tandem.

McCabe also addressed the question of the money fund industry's rank ordering of preferences. Essentially the industry wanted none of the above-neither floating NAVs nor increased capital requirements nor MBRs - but instead was leaning toward a fourth proposal: when a fund's liquidity drops below a certain level, all redemptions would be suspended or fees would be imposed. This approach would avoid taking any of the three benefits listed above off the table, at least in normal times, but in the authors' view it would heighten rather than dampen the probability of preemptive runs, contagion, and the like when markets become jittery. It was akin, McCabe remarked, to spreading kindling in a dry forest.

On the question of differentiating between institutional and retail investors, McCabe said that he and his coauthors were mindful of the fact that the latter did not run from money funds during the recent crisis. Accordingly, the paper called for an exemption from subordination for redemptions under $\$ 50,000$, but the authors were not wedded to that figure. One of the proposals offered by the Financial Stability Oversight Council suggested a $\$ 100,000$ exemption.

Replying to Reis, McCabe argued that the MBR proposal was expressly designed to give institutional managers an incentive to carefully monitor the money funds in which they were investing well in advance of any problems. He noted that the Reserve Primary Fund had maintained an extremely conservative portfolio until the summer of 2007, when it dramatically increased its yield, and it tripled its assets between August 2007 and mid-2008. But the smart money in this institutional fund believed, correctly as it turned out, that in a crisis they could get their money out before everyone else. An MBR, McCabe suggested, would have dissuaded investors from piling into this increasingly risky fund in such unstable conditions. 